\title{
Analysis of the transgenerational iron deficiency stress memory in Arabidopsis thaliana plants
}

\author{
Irene Murgia ${ }^{1 *}$, Sonia Giacometti ${ }^{1}$, Alma Balestrazzi², Stefania Paparella², \\ Cristina Pagliano ${ }^{3}$ and Piero Morandini ${ }^{1}$
}

${ }^{1}$ Department of Biosciences, University of Milano, Milano, Italy, ${ }^{2}$ Department of Biology and Biotechnology 'L. Spallanzani', University of Pavia, Pavia, Italy, ${ }^{3}$ Applied Science and Technology Department - BioSolar Lab, Polytechnic University of Turin, Alessandria, Italy

\section{OPEN ACCESS}

Edited by:

Wim Van den Ende,

KU Leuven, Belgium

Reviewed by:

Ann Cuypers,

Hasselt University, Belgium

Jean Molinier,

Centre National de la Recherche

Scientifique, France

*Correspondence:

Irene Murgia,

Department of Biosciences,

University of Milano, Via Celoria 26,

20133 Milano, Italy

irene.murgia@unimi.it

Specialty section:

This article was submitted to

Plant Physiology,

a section of the journal

Frontiers in Plant Science

Received: 18 June 2015

Accepted: 31 August 2015

Published: 17 September 2015

Citation:

Murgia I, Giacometti S, Balestrazzi A,

Paparella S, Pagliano C and Morandini P (2015) Analysis

of the transgenerational iron deficiency stress memory

in Arabidopsis thaliana plants.

Front. Plant Sci. 6:745

doi: 10.3389/fpls.2015.00745
We investigated the existence of the transgenerational memory of iron (Fe) deficiency stress, in Arabidopsis thaliana. Plants were grown under Fe deficiency/sufficiency, and so were their offspring. The frequency of somatic homologous recombination (SHR) events, of DNA strand breaks as well as the expression of the transcription elongation factor TFIIS-like gene increase when plants are grown under Fe deficiency. However, SHR frequency, DNA strand break events, and TFIS-like gene expression do not increase further when plants are grown for more than one generation under the same stress, and furthermore, they decrease back to control values within two succeeding generations grown under control conditions, regardless of the Fe deficiency stress history of the mother plants. Seedlings produced from plants grown under Fe deficiency evolve more oxygen than control seedlings, when grown under Fe sufficiency: however, this trait is not associated with any change in the protein profile of the photosynthetic apparatus and is not transmitted to more than one generation. Lastly, plants grown for multiple generations under Fe deficiency produce seeds with greater longevity: however, this trait is not inherited in offspring generations unexposed to stress. These findings suggest the existence of multiple-step control of mechanisms to prevent a genuine and stable transgenerational transmission of Fe deficiency stress memory, with the tightest control on DNA integrity.

Keywords: Arabidopsis thaliana, chlorophyll, DNA strand breaks, Fe deficiency, photosynthetic apparatus, transgenerational memory, somatic homologous recombination, seed longevity

\section{Introduction}

"Priming" in plants can be defined as the intensification of defense responses occurring against previously encountered hostile factors, usually mediated by a complex network of priming targets and mechanisms (Pastor et al., 2013a; Balmer et al., 2015). Well-known examples of priming are the systemic acquired resistance (SAR; Fu and Dong, 2013) as well as the emission of volatile organic compounds (VOCs) upon plant attack by herbivores or by exposure to abiotic stress, which can trigger systemic defense responses even in neighboring plants (Aranega-Bou et al., 2014; Lee and Seo, 2014). Early responses induced by priming mechanisms include changes in redox homeostasis and production of specific reactive oxygen species (ROS) signals, interacting with various other signaling molecules, such as hormones and reactive nitrogen species (RNS; Molassiotis et al., 2010; Mukherjee et al., 2010; Mittler et al., 2011; Pastor et al., 2013a,b). Priming can last long after 
the first exposure to stress (Conrath et al., 2006) and long-lasting responses may be mediated by chromatin remodeling, such as histone modifications and DNA methylation (Jaskiewicz et al., 2011; Paszkowski and Grossniklaus, 2011; Pastor et al., 2013a; Vriet et al., 2015).

The inheritance of the primed state in the progeny is termed transgenerational memory and its occurrence, upon a challenge with abiotic stress (UV-C) or elicitors of plants defenses (flagellin), has been demonstrated using SHR (somatic homologous recombination) trap reporter lines. SHR events restore the marker gene $\beta$-glucuronidase (GUS), whose enzymatic activity is easily detected by the well-known GUS staining method (Tinland et al., 1994; Molinier et al., 2006; Puchta and Hohn, 2012). Various analyses of the stress memory inheritance upon exposure to various abiotic (nutritional, heat stress) (Verhoeven and van Gurp, 2012; Bilichak et al., 2015) as well as biotic stresses (Luna et al., 2012; Pieterse, 2012; Rasmann et al., 2012; Slaughter et al., 2012) have been recently reported.

However, other research groups have not confirmed the existence of a genuine stress memory in successive generations. The same Arabidopsis thaliana SHR-trap lines described by Molinier et al. (2006) have been exposed to an array of different abiotic stresses (e.g., salt, osmotic, freezing, oxidative, UV-B, UV-C), revealing only a sporadic transgenerational transmission of stress memory (Pecinka et al., 2009). The authors suggest that the observed transgenerational stress effects on SHR might be occurring in a stochastic manner, and might not belong to a general defense strategy against abiotic stresses (Pecinka et al., 2009), as also suggested in Boyko et al. (2010).

Resetting pathways, responsible for the "erasure" of stress memory and for protecting plants against negative effects of the accumulation of epigenetic modifications, have been proposed (Hauser et al., 2011; Paszkowski and Grossniklaus, 2011). Indeed, the mechanism of "erasure" of the vernalized state in subsequent generations recently led to the identification of ELF6, possessing $\mathrm{H} 3 \mathrm{~K} 27$ me 3 demethylase activity (trimethylation of histone $\mathrm{H} 3$ on lysine 27) as the protein responsible for the erasure of chromatin modifications regulating the floral repressor locus FLC (Crevillen et al., 2014).

Moreover, a screen for Arabidopsis mutants impaired in the erasure of epigenetic stress memory, identified the nucleosome remodeller Morpheus' Molecule 1 MOM1 as a chromatin regulator acting in the restoration of the Arabidopsis epigenome to a pre-stress condition, together with another chromatin regulator Decrease in DNA Methylation 1 DDM1 (Iwasaki and Paszkowski, 2014). The analysis of loci activated by heat stress and still transgenerationally active in $d d m 1$ mom 1 double mutants progeny plants identified 340 genes, out of around a total 3000 genes activated by same stress conditions (Tittel-Elmer et al., 2010), suggesting that DDM1 and MOM1 control only a fraction of the erasure of the transgenerational stress memory (Iwasaki and Paszkowski, 2014).

Up to now, no studies on plant transgenerational stress memory occurring under Fe deficiency have been reported, and with the present work we therefore intend to fill such a gap in knowledge.
Iron is an essential element for plants, since it is involved in a wide range of housekeeping functions; iron is also involved in the response to biotic and abiotic stresses (Jeong and Guerinot, 2009; Ravet et al., 2009; Kieu et al., 2012; Ravet and Pilon, 2013; Briat et al., 2015). Research on the mechanisms by which plants acquire Fe from the soil through the roots and transport it to sink organs, without incurring the toxic effects of the free, redox-active form of $\mathrm{Fe}$, has led to quite a complex view of regulation of $\mathrm{Fe}$ homeostasis and trafficking, from subcellular organelle to whole plant system (Kobayashi and Nishizawa, 2012; Vigani et al., 2013; Briat et al., 2015).

Plant growth and development are severely impaired when Fe uptake from the soil through the root apparatus is unable to satisfy the $\mathrm{Fe}$ demand of aerial parts and sink organs. Fe deficiency most frequently occurs when plants are grown in alkaline soils, where Fe solubility is reduced; such nutritional stress represents a severe burden for agriculture, in term of productivity and crop quality and, in turn, for human nutrition (Murgia et al., 2012, 2013; Briat et al., 2015).

In the present work we investigated the existence of the transgenerational Fe deficiency memory in A. thaliana plants. An SHR-trap line (Molinier et al., 2006; Puchta and Hohn, 2012) and wt control line (ecotype $\mathrm{Col}$ ) were grown in various experimental conditions of Fe deficiency. The Fe deficiency memory was evaluated in subsequent generations, exposed or not to stress, by following DNA damage, SHR events, expression of transcription elongation factor II-S (TFIIS and TFIIS-like) genes as well as physiological parameters (chlorophyll content, $\mathrm{O}_{2}$ evolution, protein profile of the photosynthetic apparatus, seed longevity).

\section{Materials and Methods}

\section{Arabidopsis thaliana Growth}

Arabidopsis thaliana wt Col and SHR-trap 1445 line (background $\mathrm{Col})$ were grown in control or alkaline soil, in a greenhouse at $21-25^{\circ} \mathrm{C}, 100 \mu \mathrm{E} \mathrm{m} \mathrm{m}^{-2} \mathrm{~s}^{-1}$, in long day conditions (16 h/8 h light/dark) unless otherwise specified, and watered with deionized water. Control soil was Technic n.1 DueEmme (Netherlands; $\mathrm{pH}$ 6.6) whereas alkaline soil ( $\mathrm{pH} 7.7$ or $\mathrm{pH} 8.4$ ) was prepared by supplementing Technic n.1 soil with $\mathrm{CaO}$ (6 and $8 \mathrm{~g} \mathrm{CaO} / \mathrm{kg}$ soil, respectively). Soil was then moistened with water and thoroughly hand-mixed, its $\mathrm{pH}$ measured after few hours and adjusted with further supplements of $\mathrm{CaO}$, as needed. Soil was then mixed again and its $\mathrm{pH}$ measured several times in the next 2 days and each time adjusted to the target $\mathrm{pH}$ with $\mathrm{CaO}$, before use. At the end of the experiments, $\mathrm{pH}$ of alkaline soils was measured again; the observed decrease in $\mathrm{pH}$ (even after prolonged growth, as in case of plants grown till maturity for seed collection) was never higher than $0.2 \mathrm{pH}$ units.

Sterilized A. thaliana seeds (45-60 seeds/plate) were placed on square Petri dishes $(10 \mathrm{~cm} \times 10 \mathrm{~cm})$ containing AIS medium with either $50 \mu \mathrm{M}$ final concentration Fe(III)-EDTA (indicated as control, +Fe; Murgia et al., 1998), or without Fe addition (indicated as $-\mathrm{Fe}$ ). 


\section{Seeds Collection, Maintenance, and Sterilization}

Seeds were collected from mature brownish siliques and, after 1 week maintenance at room temperature, were either stored at $-20^{\circ} \mathrm{C}$ (preserved seeds) or stored at room temperature for various time-lengths. Seeds were surface sterilized by fumigation with chlorine fumes; for that, seeds were placed in microcentrifuge tubes and placed open, in a desiccator jar. Immediately prior to sealing the jar, $3 \mathrm{ml}$ of concentrated $\mathrm{HCl}$ were added to a solution of $15 \%$ bleach and seeds were kept inside the jar for 3-4 h.

\section{$\mathrm{O}_{2}$ Evolution and Chlorophyll Quantification}

Oxygen evolution was measured with a Clark-type oxygen electrode (Hansatech, Ltd., King's Lynn, Norfolk, UK) at $25^{\circ} \mathrm{C}$ by using a leaf disk electrode chamber. Seedlings (11 daysold, 30-50 mg each independent sample) were mounted in a sealed gas-tight chamber. Calibration was performed with $1 \mathrm{~mL}$ air at $25^{\circ} \mathrm{C}, 101.32 \mathrm{kPa}$ containing $8.58 \mu \mathrm{mol} \mathrm{O}_{2}$. Prior to measurements, $200 \mu \mathrm{l}$ bicarbonate buffer $\left(1 \mathrm{M} \mathrm{Na}_{2} \mathrm{CO}_{3}: 1 \mathrm{M}\right.$ $\left.\mathrm{NaHCO}_{3}: 1: 9\right)$ was added in the chamber. Net oxygen rates were measured at two light intensities (100 and $800 \mu \mathrm{E} \mathrm{m}^{-2} \mathrm{~s}^{-1}$ ) and analyzed with OxylabV1.15 software. Seedlings were then removed from the chamber and put in a vial containing $1-3 \mathrm{ml}$ dimethylformamide for chlorophyll extraction. Chlorophyll extraction and quantification was performed according to Tarantino et al. (2005).

\section{Comet Assay}

For nuclei extraction, A. thaliana seedlings (14 days-old, 90 seedlings per independent sample, roughly corresponding to $100-200 \mathrm{mg}$ ) were frozen in liquid nitrogen, immediately chopped with a sharp blade and transferred into $400 \mu \mathrm{l}$ of Chopping solution (PBS 1X, 10 mM EDTA, pH 7.0). The nuclei suspension was then filtered with a $50 \mu \mathrm{m}$ mesh funnel (Sysmex Partec GmbH, Görlitz, Germany) and subsequently mixed with $300 \mu \mathrm{l}$ of $1 \%(\mathrm{w} / \mathrm{v})$ low melting point agarose (Sigma-Aldrich, Milan, Italy) in phosphate-buffered saline (PBS) buffer at $37^{\circ} \mathrm{C}$. Two drops of the resulting suspension were then pipetted onto agarose precoated slides and solidified on ice. To let the DNA unwind for the detection of single strand breaks (SSBs) and double strand breaks (DSBs), slides were incubated for $20 \mathrm{~min}$ in the dark, at $4^{\circ} \mathrm{C}$, in Alkaline Buffer $(1 \mathrm{mM}$ EDTA, $300 \mathrm{mM}$ $\mathrm{NaOH}, \mathrm{pH}$ 13.0). The slides were neutralized by washing in TBE buffer ( $89 \mathrm{mM}$ Tris base, $89 \mathrm{mM}$ Boric acid, $2 \mathrm{mM}$ EDTA), and then electrophoresed in the same buffer for $5 \mathrm{~min}, 1 \mathrm{~V} \mathrm{~cm}^{-1}$, at $4^{\circ} \mathrm{C}$ in the dark. After electrophoresis, slides were washed in $70 \%(\mathrm{v} / \mathrm{v})$ ethanol for $5 \mathrm{~min}$, in ethanol $100 \%$ for $10 \mathrm{~min}$ and allowed to dry overnight at room temperature. Slides were stained with $20 \mu \mathrm{l}$ of DAPI (4',6-diamidino-2-phenylindole; $1 \mu \mathrm{g} \mathrm{ml}^{-1}$, Sigma-Aldrich; Menke et al., 2000). For each slide, 100 nucleoids were scored using a fluorescence microscope (Leica DM4000 B LED, Leica Microsystems GmbH, Wetzlar, Germany) with an excitation filter of 340-380 nm and a barrier filter of $400 \mathrm{~nm}$. Nucleoids were classified and results were expressed in arbitrary units (a.u.) according to Collins (2004). For each treatment, three replicated samples were analyzed in two independent experiments.

\section{GUS Staining}

$\beta$-Glucuronidase staining solution $[1 \mathrm{mM}$ sodium phosphate buffer $\mathrm{pH} 7.0,10 \mathrm{mM}$ EDTA, $0.3 \%$ Triton-X (v/v), $2 \mathrm{mM}$ potassium ferrocyanide, $2 \mathrm{mM}$ potassium ferricyanide, $0.5 \mathrm{mg} / \mathrm{ml}$ $\mathrm{X}$-glucuronide] was infiltrated into submerged $A$. thaliana 2-3 weeks-old leaves (20-120 mg weight range of each sampled leaf) or 11 days-old seedlings by vacuum, for about $2 \mathrm{~h}$. Samples were then incubated overnight at $37^{\circ} \mathrm{C}$ in the dark, rinsed in distilled water and destained $1 \mathrm{~h}$ in acetic acid/ethanol solution $(3: 1 \mathrm{v} / \mathrm{v})$ and a final rinse in $70 \%(\mathrm{v} / \mathrm{v})$ ethanol. SHR events, revealed as blue sectors, were evaluated and counted under a stereomicroscope (Leica).

\section{Quantitative Real-Time Polymerase Chain Reaction (qRT-PCR)}

RNA was extracted from seedlings (after 14 days from germination) with TRIzol ${ }^{\circledR}$ reagent (Life Technologies, Carlsbad, CA, USA), by following manufacturer's instructions. qRT-PCR was carried out using the iTaq ${ }^{\mathrm{TM}}$ universal $\mathrm{SYBR}^{\circledR}$ Green onestep kit (Bio-Rad Laboratories, Hercules, CA, USA) using a Rotor-Gene 6000 PCR apparatus (Corbett Robotics Pty Ltd., Brisbane, QLD, Australia). Reaction conditions were as follows: reverse transcription at $50^{\circ} \mathrm{C}$ for $10 \mathrm{~min}$, denaturation at $95^{\circ} \mathrm{C}$ for $1 \mathrm{~min}$, and 40 cycles of $95^{\circ} \mathrm{C} 15 \mathrm{~s}$ and $60^{\circ} \mathrm{C}$ 30 s. After the amplification a melting reaction was carried out. The expression profiles of $A$. thaliana TFIIS gene (TAIR annotation At2g38560) and TFIIS-like gene (TAIR annotation At5g09850; Macovei et al., 2011) were obtained by using $\beta$-Tubulin (TAIR annotation At1g20010) and Ubiquitin4 (TAIR annotation At5g20620) as reference genes. Primers were designed with the Primer Design online tool Primer $3^{1}$ and checked with an OligoAnalyzer tool (Integrated DNA Technologies ${ }^{2}$ ). For each oligonucleotide set, a no-template water control was used. qRTPCR data analysis was carried out according to Vandesompele et al. (2002). Statistical analysis was performed with SigmaStat (Systat Software, Richmond, CA, USA).

\section{Thylakoid Isolation}

Arabidopsis thaliana seedlings (11 days-old, around 200-600 mg each independent sample) were frozen in liquid nitrogen and ground to obtain a fine powder, which was further homogenized in $50 \mathrm{mM}$ HEPES- $\mathrm{NaOH}, \mathrm{pH} 7.2,5 \mathrm{mM} \mathrm{MgCl} 2,10 \mathrm{mM}$ $\mathrm{NaCl}$, and $0.5 \mathrm{M}$ sucrose. The homogenate was filtered through six layers of cotton cloth, then membranes were pelleted by centrifugation for $10 \mathrm{~min}$ at $3,000 \mathrm{~g}$ at $4^{\circ} \mathrm{C}$. Pellets were resuspended in previous buffer devoid of sucrose and spun down for $10 \mathrm{~min}$ at $4,500 \mathrm{~g}$. Finally, thylakoids were resuspended in $50 \mathrm{mM}$ HEPES-NaOH, pH 7.2, $5 \mathrm{mM} \mathrm{MgCl}_{2}, 10 \mathrm{mM} \mathrm{NaCl}$, and $0.1 \mathrm{M}$ sucrose. The chlorophyll concentration was determined spectrophotometrically after extraction in $80 \%(\mathrm{v} / \mathrm{v})$ acetone according to Arnon (1949).

\footnotetext{
${ }^{1}$ http://primer3.ut.ee

${ }^{2}$ https://eu.idtdna.com/calc/analyzer
} 


\section{Gel Electrophoresis and Western Blotting}

Sodium dodecylsulfate polyacrylamide gel electrophoresis (SDSPAGE) was performed on a $12.5 \%(\mathrm{w} / \mathrm{v})$ polyacrylamide gel containing $5 \mathrm{M}$ urea using Laemmli's system (Laemmli, 1970); pre-stained protein markers (Precision plus, Bio-Rad) were used for the estimation of apparent molecular mass of the main thylakoid proteins. After electrophoretic separation, proteins were either detected by using a silver staining protocol, as described in Shevchenko et al. (1996), or transferred onto a nitro-cellulose membrane. Further immunodetection was performed with specific antisera against PsaA, CP43, PsbO, D1, PsbE (Agrisera codes AS06172, AS111787, AS05092, AS05084, AS06112, respectively) and LHCII polypeptides, by using the alkaline phosphatase conjugate method, with 5-bromo-4-chloro3-indolyl phosphate/nitro blue tetrazolium as chromogenic substrates (Sigma-Aldrich).

\section{Correlation and Statistical Analysis}

Correlation analysis was performed as described in Menges et al. (2008) and Berri et al. (2009), both in the linear and in the log space. Statistical analysis was performed by using Student's $t$-test.

\section{Results}

\section{A. thaliana Plants Grown under Fe Deficiency Show Enhanced SHR Frequency with a Subsequent Decrease within Two Generations Grown under Fe Sufficiency}

Arabidopsis thaliana wt Col plants (control generation $\mathrm{c} 0$ ) were grown in either of two alkaline soils, at either $\mathrm{pH} 7.7$ or $\mathrm{pH} 8.4$.
The collected seeds represent the stressed progeny generation 1 ("pH 7.7 s1" and "pH 8.4 s1," respectively).

$\mathrm{Col} \mathrm{pH} 7.7 \mathrm{~s} 1$ and $\mathrm{pH} 8.4 \mathrm{~s} 1$ plants, when grown either in control, pH 7.7 (Supplementary Figures S1A,B) or pH 8.4 soil (Supplementary Figure S1C), show higher biomass production than corresponding c0 plants grown in the same conditions (Supplementary Figure S1), thus suggesting the existence of a memory of Fe deficiency stress in the offspring. To confirm the existence of a genuine transgenerational memory, the SHR-trap line 1445 (control generation $\mathrm{c} 0$ ), was grown in either of two alkaline soils, at either $\mathrm{pH} 7.7$ or 8.4 , with production of $\mathrm{pH} 7.7$ s1 and pH 8.4 s1 generation seeds, respectively (Figure 1).

Both wt Col and SHR-trap line 1445 pH 7.7 s1 and pH 8.4 s1 generations were then grown in control, $\mathrm{pH} 7.7$ or $\mathrm{pH} 8.4$ soil. The resulting generation 2 seeds were named $\mathrm{pH} 7.7 \mathrm{~s} 1 \mathrm{pH} 7.7$ s2 and $\mathrm{pH} 8.4 \mathrm{~s} 1 \mathrm{pH} 8.4 \mathrm{~s} 2$ respectively, whereas seeds produced from an $\mathrm{s} 1$ generation grown in control soil were named $\mathrm{pH}$ 7.7 s1 c2 and pH 8.4 s1 c2, respectively. Progeny seeds from c0 plants grown in control soil were named c0 seeds. A scheme summarizing the different steps in the production of the plant lines and the relative nomenclature, is shown in Figure 1.

Frequency of SHR events was then evaluated in the following SHR-trap 1445 generations: c0 (Figure 2A), s1 (Figure 2B), s1s2 and s1c2 (Figure 2C); for that, they were grown in control, $\mathrm{pH}$ 7.7 or $\mathrm{pH} 8.4$ soil followed by GUS staining of leaves. SHR frequency in $\mathrm{c} 0$ plants grown at either $\mathrm{pH} 7.7$ or $\mathrm{pH} 8.4$ is roughly ten times higher than that observed in $\mathrm{c} 0$ plants grown in control soil (Figure 2A). Such higher SHR frequency was maintained, though it did not increase further in plants grown under Fe deficiency and produced from mother plants which were also grown under the same stress, as shown for $\mathrm{pH} 7.7$

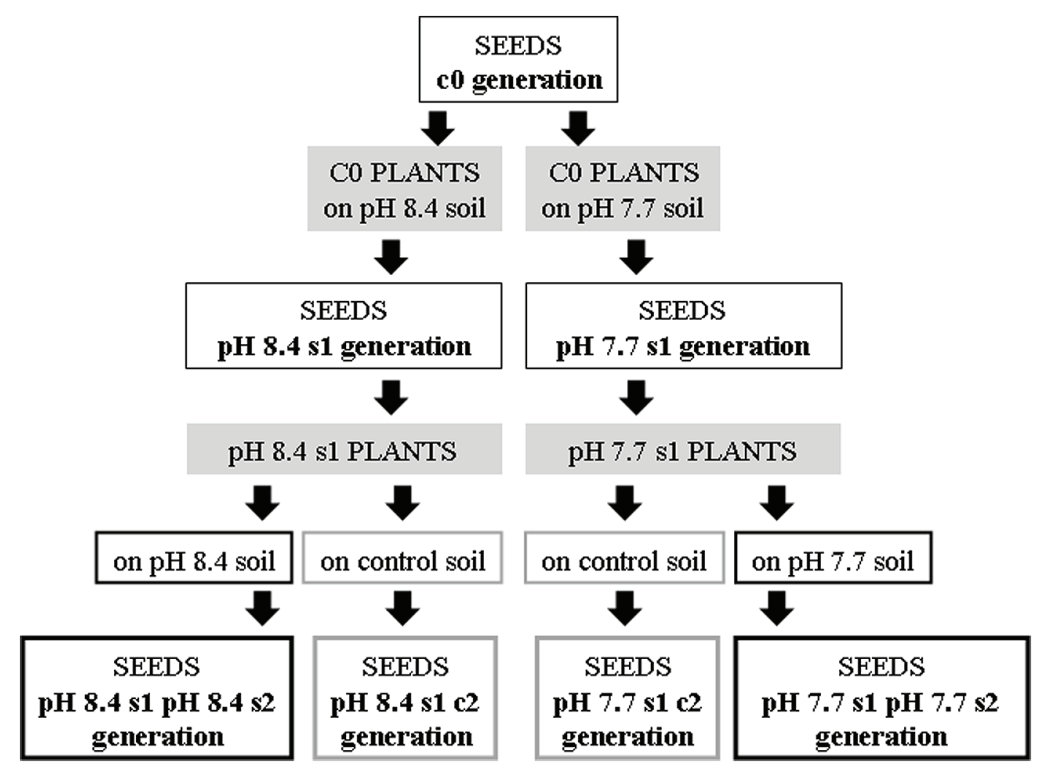

FIGURE 1 | Production of the Arabidopsis thaliana plants with generational exposure to Fe deficiency. A. thaliana wt ecotype Col or $A$. thaliana SHR-trap 1445 line (background Col) were used as control c0 generation (c0 seeds). c0 seeds grown in control soil produced seeds that are still named c0; c0 seeds grown in either $\mathrm{pH} 7.7$ or $\mathrm{pH} 8.4$ soil produced $\mathrm{pH} 7.7$ s1 or $\mathrm{pH} 8.4$ s1 seeds, respectively. $\mathrm{pH} 7.7$ s1 seeds grown in either $\mathrm{pH} 7.7$ or control soil produced $\mathrm{pH} 7.7$ s1 pH 7.7 s2 or pH 7.7 s1 c2 seeds, respectively. pH 8.4 s1 seeds grown in either pH 8.4 or control soil produced pH 8.4 s1 pH 8.4 s2 or pH 8.4 s1 c2 seeds, respectively. 


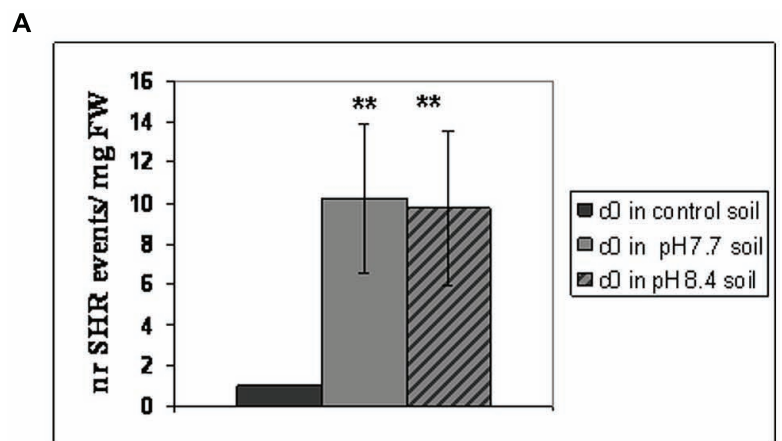

B

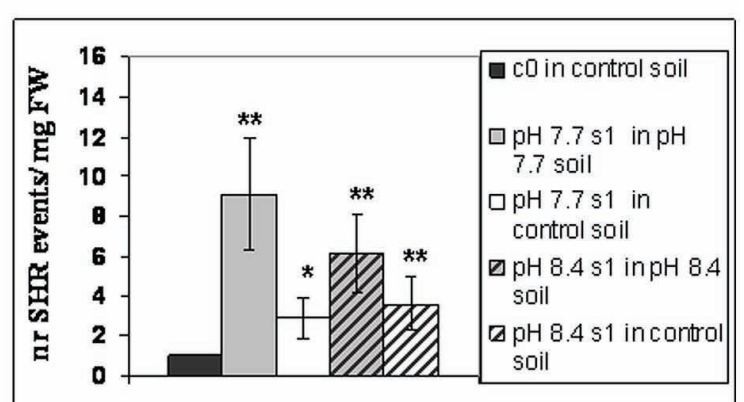

C

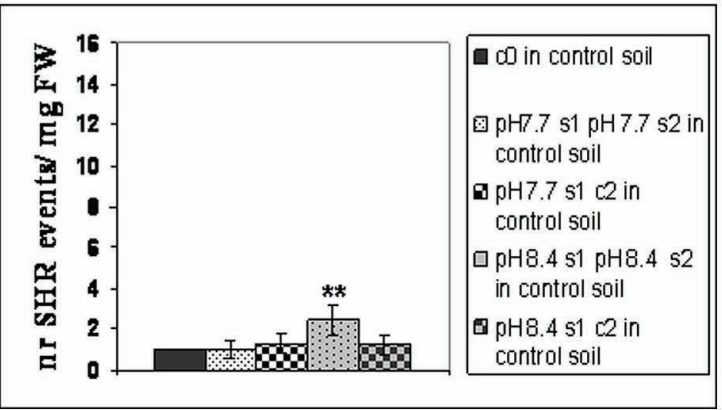

FIGURE 2 | Somatic homologous recombination (SHR) in A. thaliana plants with generational exposure to Fe deficiency and grown under Fe deficiency or sufficiency. (A) $A$. thaliana SHR-trap $1445 \mathrm{c} 0$ plants grown in control, $\mathrm{pH} 7.7$ or $\mathrm{pH} 8.4$ soil. (B) s1 plants $(\mathrm{pH} 7.7 \mathrm{~s} 1$ and $\mathrm{pH} 8.4$ s1) grown in control, $\mathrm{pH} 7.7$ or $\mathrm{pH} 8.4$ soil. (C) s1s2 and s1c2 plants $(\mathrm{pH} 7.7$ s1 pH 7.7 s2, pH 8.4 s1 pH 8.4 s2, pH 7.7 s1 c2, pH 8.4 s1 c2) grown in control soil. For all experiments, plants were grown for 2-3 weeks and rosette leaves were GUS-stained for detection of SHR events, counted as number of independent blue spots/mg fresh weight. Each value represents the mean spots number \pm SE in five to twenty leaves. Significant differences (with respect to control $\mathrm{c0}$ value) are indicated with $* *(p<0.01)$ or $*(p<0.05)$, according to Student's $t$-test.

s1 grown in $\mathrm{pH} 7.7$ soil and $\mathrm{pH} 8.4$ s1 grown in $\mathrm{pH} 8.4$ soil (Figure 2B). The lack of additive effect suggests a control of SHR frequency, with a plateau effect. Notably, when either $\mathrm{pH} 7.7 \mathrm{~s} 1$ or $\mathrm{pH} 8.4 \mathrm{~s} 1$ are grown in control soil, the SHR frequency was drastically reduced (Figure 2B) but was still higher than control, suggesting occurrence of a faint "stress memory." Such memory was, however, completely erased when plants were grown for two successive generations in control soil, as was evident in $\mathrm{pH}$ $7.7 \mathrm{~s} 1 \mathrm{c} 2$ and $\mathrm{pH} 8.4 \mathrm{~s} 1 \mathrm{c} 2$ generations grown again in control soil (Figure 2C). It is also interesting to note that growth for two successive generations under Fe deficiency did not reinforce

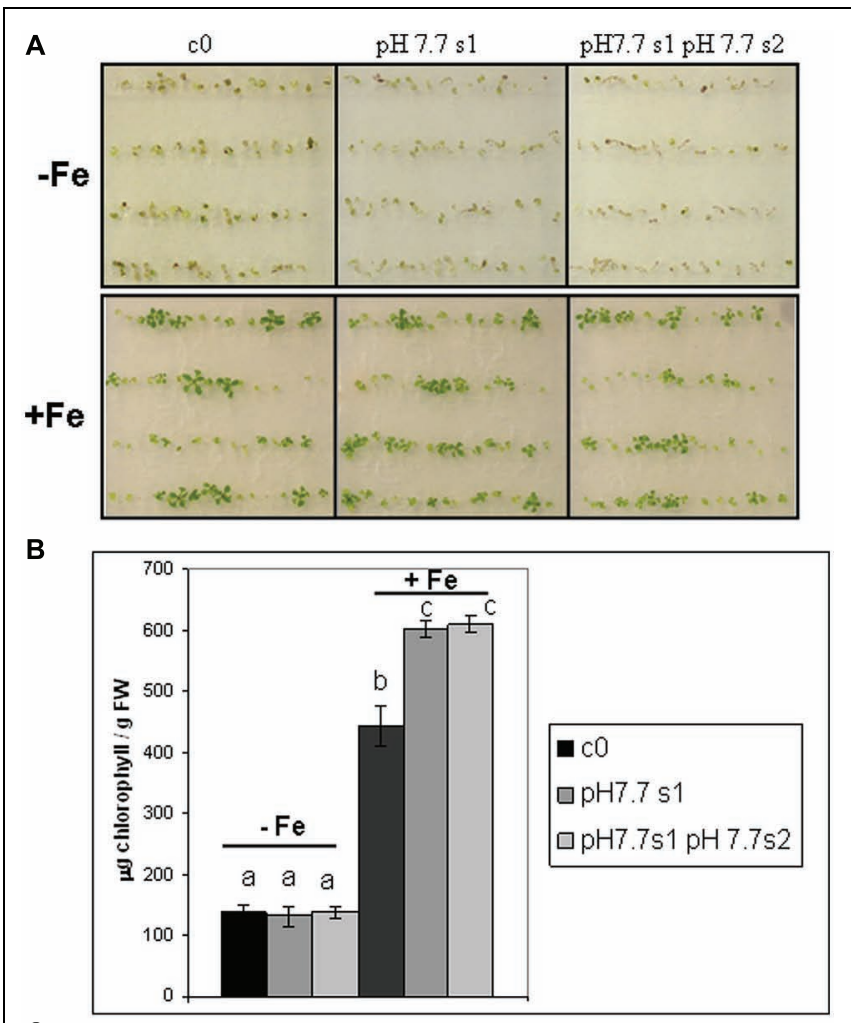

C

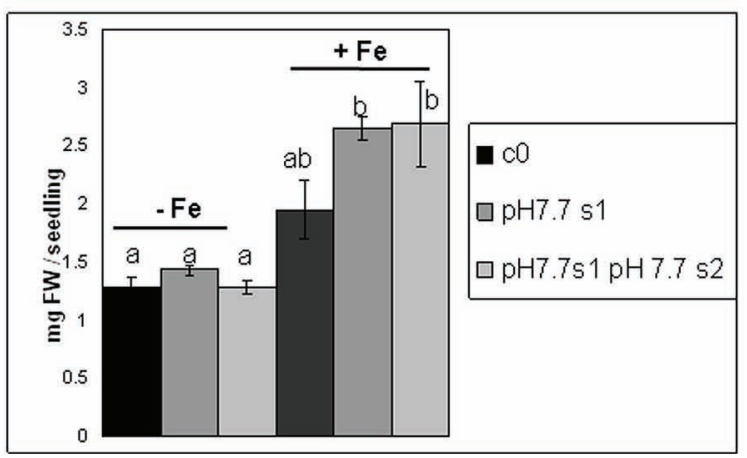

FIGURE 3 | Arabidopsis thaliana seedlings with generational exposure to Fe deficiency and grown under Fe deficiency or sufficiency.

(A) A. thaliana SHR-trap 1445 seedlings, from either control generation (c0) or from single ( $\mathrm{pH} 7.7 \mathrm{~s} 1)$ or multiple generational exposure to Fe deficiency $(\mathrm{pH}$ $7.7 \mathrm{~s} 1 \mathrm{pH} 7.7 \mathrm{~s} 2)$ germinated for 11 days in control AIS medium (+Fe), or AIS medium without Fe (-Fe). (B) Chlorophyll content, expressed as mg chlorophyll/g fresh weight of seedlings described in (A). (C) Weight (expressed as $\mathrm{mg}$ fresh weight/seedling) of seedlings described in (A). Bars represent mean values $\pm \mathrm{SE}$, from at least three biological samples consisting of twenty seedlings each. Significant differences are indicated with letters $(p<0.05)$, according to Student's t-test.

stress memory in offspring unexposed to stress, as observed in $\mathrm{pH}$ $7.7 \mathrm{~s} 1 \mathrm{pH} 7.7 \mathrm{~s} 2$ and $\mathrm{pH} 8.4 \mathrm{~s} 1 \mathrm{pH} 8.4 \mathrm{~s} 2$ lines, grown in control soil (Figure 2C).

Taken together, these results show that the number of SHR events increased in plants grown under Fe deficiency, both in mild or in severe alkaline soil and that frequency of SHR events returned to control values within two generations unexposed to 
A

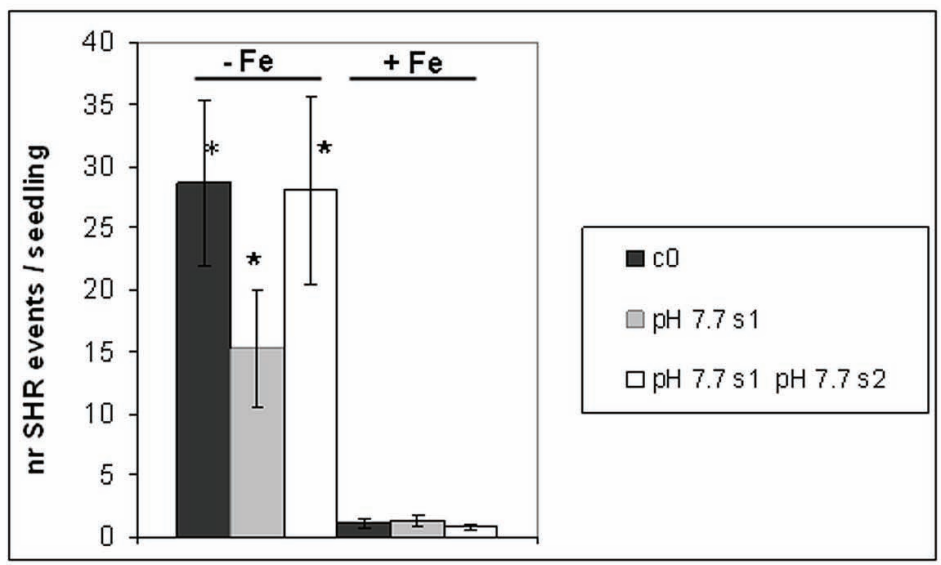

B

$\mathrm{co}$ $\mathrm{pH} 7.7 \mathrm{~s} 1$ $\mathrm{pH} 7.7 \mathrm{~s} 1 \mathrm{pH} 7.7 \mathrm{~s} 2$

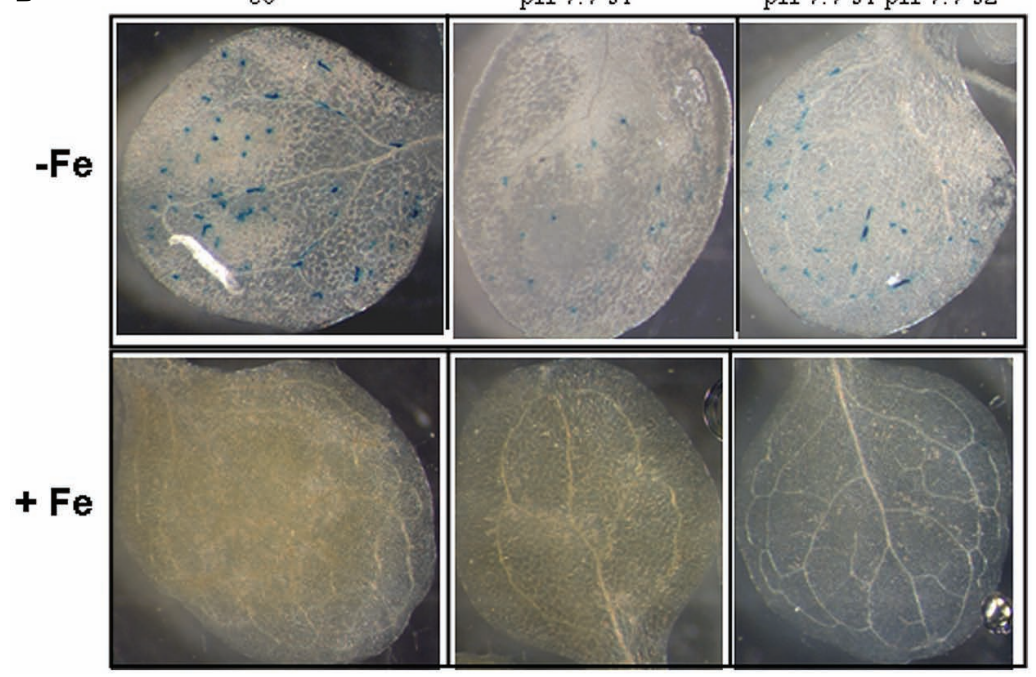

FIGURE 4 | Somatic homologous recombination events in $A$. thaliana seedlings with generational exposure to Fe deficiency and grown under Fe deficiency or sufficiency. (A) SHR events in A. thaliana SHR-trap 1445 seedlings, from control generation (c0), from single (pH 7.7 s1) or multiple generational exposure to Fe deficiency (pH $7.7 \mathrm{~s} 1 \mathrm{pH} 7.7 \mathrm{~s} 2)$ grown for 11 days in control AIS medium (+Fe), or in AIS medium without Fe (-Fe). Seedlings were stained for GUS expression and SHR events evaluated as number of spots/seedling. Values are the mean spot number \pm SE in ten seedlings. Significant differences (with respect to control $c 0$ ) are indicated with * $(p<0.05)$, according to Student's $t$-test. (B) Representative seedlings, described in (A), stained for detection of GUS activity.

stress. Moreover, growth of more than one generation in alkaline soil was not associated with a higher frequency of SHR events.

To reduce any variability of results resulting from stunted growth occurring in alkaline soil, SHR frequency was also measured in $\mathrm{c} 0, \mathrm{pH} 7.7 \mathrm{~s} 1$ and $\mathrm{pH} 7.7 \mathrm{~s} 1 \mathrm{pH} 7.7 \mathrm{~s} 2$ seedlings, when germinated on control AIS medium $(+\mathrm{Fe})$ or in AIS medium without iron supplement $(-\mathrm{Fe})$ (Figure 3A). All tested seedlings growing under Fe deficiency were equally affected, in terms of chlorophyll content (Figure 3B). Both pH $7.7 \mathrm{~s} 1$ and $\mathrm{pH} 7.7$ s1 pH 7.7 s2 seedlings, grown in $+\mathrm{Fe}$, showed instead a significantly higher chlorophyll content (but not significantly higher fresh weight), with respect to their control c0 seedlings in the same condition (Figures 3B,C). As already observed for SHR frequency (Figure 2), chlorophyll content and seedlings fresh weight did not further increase upon exposure to Fe deficiency for multiple generations (Figures 3B,C). SHR frequency was measured in seedlings treated as described in Figure 3; results confirm that Fe deficiency strongly enhanced SHR frequency, as observed for SHR-trap seedlings c0, pH 7.7 s1, pH 7.7 s1 pH 7.7 s2 grown under Fe deficiency (Figure 4), thus confirming the observations about plants grown on alkaline soil (Figure 2).

As also observed with plants grown in soil, SHR frequency was not enhanced further in seedlings exposed for more than one generation to Fe deficiency stress (Figure 4A), suggesting again the plateau effect mentioned above. Vice-versa, unstressed offspring seedlings of stress-treated plants, had an SHR frequency similar to $\mathrm{c}$, when grown in control soil (Figure 4A).

These results show that the number of SHR events increased in seedlings grown under Fe deprivation and that the frequency of SHR events returned to control values within one generation grown under Fe sufficiency. Moreover, growth of more than one generation under Fe deprivation was not associated with a 
higher frequency of SHR events, thus confirming observations with plants grown in alkaline soil.

\section{DNA Damage Profiles and Expression of the TFIIS-like Gene are Enhanced in A. thaliana Seedlings Grown under Fe Deficiency but Neither in s1 nor in s1s2 Generations Grown under Fe Sufficiency}

Genotoxic stress in plants is generally regarded as a main factor which affects genome stability, impairing productivity (Balestrazzi et al., 2011; Waterworth et al., 2011). Since the genotoxic impact of Fe deficiency is still unexplored in plants, an investigation was carried out to assess the DNA damage profiles occurring under Fe deficiency, using the Alkaline SCGE (single cell gel electrophoresis, or Comet assay), which measures both SSBs and DSBs.

DNA lesions were quantified in nuclei isolated from SHRtrap $1445 \mathrm{c} 0, \mathrm{pH} 7.7 \mathrm{~s} 1, \mathrm{pH} 7.7 \mathrm{~s} 1 \mathrm{pH} 7.7$ s2 seedlings, when germinated in control $(+\mathrm{Fe})$ or in $-\mathrm{Fe}$ medium. Control c0 seedlings grown in $+\mathrm{Fe}$ showed a DNA damage value of $130.6 \pm 41.7$ a.u., which can be attributed to the experimental manipulations of nuclei; such a value is similar to those quantified in both pH $7.7 \mathrm{~s} 1$ seedlings (127.4 \pm 17.5 a.u.) and $\mathrm{pH} 7.7 \mathrm{~s} 1 \mathrm{pH}$ 7.7 s2 seedlings (123.6 \pm 33.2 a.u.), when in $+\mathrm{Fe}$ (Figure 5A). Vice-versa, as already observed for the SHR events, the extent of DNA damage increased in c0 seedlings (208.3 \pm 25.3 a.u.), in $\mathrm{pH} 7.7$ s1 seedlings $(198.8 \pm 28.4$ a.u. $)$ and in $\mathrm{pH} 7.7 \mathrm{~s} 1$ pH7.7 s2 seedlings $(191.0 \pm 22.1$ a.u. $)$, under Fe deficiency (-Fe; Figure 5A). Moreover, in accordance with the SHR events, growth for more than one generation under Fe deficiency did not further increase DNA damage, as such values measured in - Fe $\mathrm{pH} 7.7 \mathrm{~s} 1$ and $-\mathrm{Fe} \mathrm{pH} 7.7 \mathrm{~s} 1 \mathrm{pH} 7.7$ s2 seedlings were similar (Figure 5A).

These results show that DNA damage increased in seedlings grown under Fe deprivation and that it returned to control values within one generation grown under Fe sufficiency. Moreover, growth of more than one generation under Fe deprivation was not associated with a more pronounced DNA damage, as also observed for SHR events.

Mechanisms involved in genome protection include nucleotide excision repair (NER; Fousteri and Mullenders, 2008), which operates through the TC (transcript-coupled) sub-pathway to remove DNA lesions and block RNA polymerase II and restore transcription. One of the components of TC-NER pathway is the transcription elongation factor TFIIS, which associates with RNA polymerase II, possibly enabling repair under UV-C exposure (Lagerwerf et al., 2011).

Plants possess the TFIIS gene (At2g38560/RDO2) which is involved in the regulation of seed dormancy and development, as described for Arabidopsis by Grasser et al. (2009) and Mortensen and Grasser (2014). Also, TFIIS-like genes have been identified and characterized in Medicago truncatula (Macovei et al., 2011) and rice (Oryza sativa L.) (Macovei et al., 2014); such genes encode proteins sharing some common features with the canonical TFIIS proteins. Both genes are responsive to genotoxic stress induced by $\mathrm{x}$-ray and salinity stress in seedlings and mature plants (Macovei et al., 2014). A gene with $60 \%$ similarity to MtTFIIS-like, according to Phytozome (v10.23 , Goodstein et al., 2012), is present in the A. thaliana genome, namely At5g09850 gene, which we therefore named AtTFIIS-like. Alignment of protein sequences of AtTFIIS-like and MtTFIIS-like (Medtr3g095380, according to Phytozome) is shown in Supplementary Figure S2 where the TFIIS domain is highlighted. Both TFIIS-like proteins share the LW motif, required to accomplish the nuclear import of proteins (Ling et al., 2006).

The expression profiles of both AtTFIIS and AtTFIIS-like genes were studied by qRT-PCR in SHR-trap $1445 \mathrm{c} 0$, pH 7.7 s1, pH7.7 $\mathrm{s} 1 \mathrm{pH} 7.7 \mathrm{~s} 2$ seedlings germinated in control $(+\mathrm{Fe})$ or in $-\mathrm{Fe}$. As shown in Figure 5B, TFIIS expression was not dependent either on the Fe nutritional status, or on the stress pedigree of the tested lines, being similar in all tested seedlings, when grown in $+\mathrm{Fe}$ as well as in - Fe (Figure 5B). On the other hand, the expression of the TFIIS-like gene significantly increased in all seedlings $(\mathrm{c} 0, \mathrm{pH}$ $7.7 \mathrm{~s} 1, \mathrm{pH} 7.7 \mathrm{~s} 1 \mathrm{pH} 7.7 \mathrm{~s} 2)$ grown in $-\mathrm{Fe}$, compared with what was observed in $+\mathrm{Fe}$ (Figure 5B).

These results show that expression of the AtTFIIS-like gene increased in seedlings grown under $\mathrm{Fe}$ deprivation and that such expression returned to control values within one generation grown under Fe sufficiency. Moreover, growth of more than one generation under Fe deprivation was not associated with an increased expression of the AtTFIIS-like gene.

Correlation analysis of gene expression has been successfully applied for identifying new candidate genes for a given biological process (Beekwilder et al., 2008; Murgia et al., 2011). Such analysis, was performed on At2g38560 (TFIIS/RDO2), At5g09850 (TFIIS-like), At1g01210, At2g13640, At2g27780, At3g25940, At3g48060, At4g07950, At4g18720, At4g24200, At5g05140, At5g27310 and At5g51360, i.e., all the A. thaliana genes, which are annotated as TFIIS or similar, according to the Arabidopsis Information resource $\left(\mathrm{TAIR}^{4}\right)$, and detected by the ATH1 Affymetrix microarray gene chip. However, the analysis did not detect any strong positive correlation between any of the tested genes and the genes involved in the Fe-deficiency response (e.g., FRO1, FIT1, IRT1, Popeye, etc.) with a threshold for the Pearson's coefficient set to 0.6 (data not shown).

AtTFIIS-like has been identified as one of the putative proteins forming subunit 26 of the Mediator complex, and named AtMed26_3 (Mathur et al., 2011); interestingly, Mediator subunit 16 gene (At4g04920), which is also part of the Mediator complex representing a bridge between RNA polymerase and specific transcriptional activators, functions in the regulation of iron homeostasis (Yang et al., 2014; Zhang et al., 2014). Correlation analysis of MED16 did not reveal a strong correlation with any of the Fe deficiency response genes whose expression is MED16dependent and reported in Zhang et al. (2014) (data not shown). Results of such correlation analyses, together with the evidence that MED16 exerts a profound impact on the Fe deficiency response without changing its expression under Fe deprivation (Zhang et al., 2014), suggests that the alteration of TFIIS-like gene

\footnotetext{
${ }^{3}$ http://phytozome.jgi.doe.gov/pz/portal.html

${ }^{4}$ https://www.arabidopsis.org/
} 
A

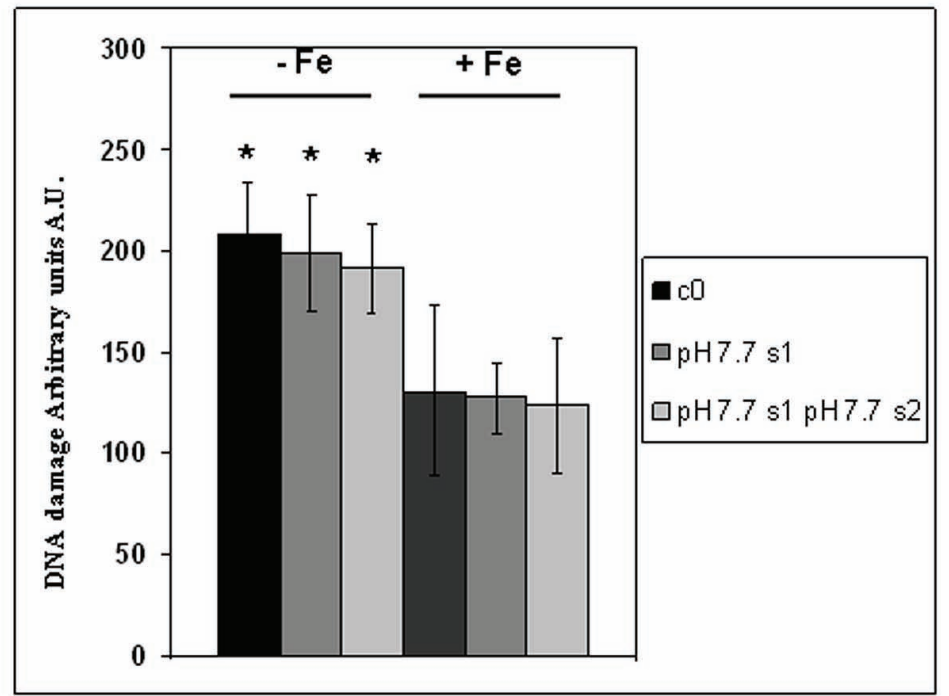

B

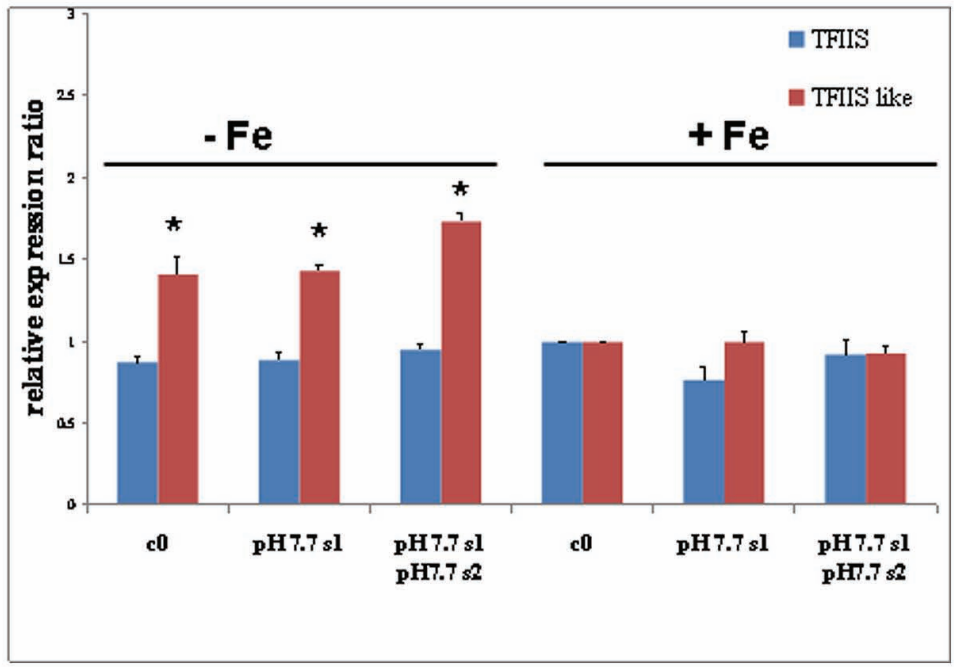

FIGURE 5 | DNA damage and expression of AtTFIIS and AtTFIIS-like genes, in A. thaliana seedlings with generational exposure to Fe deficiency and grown in control AIS medium (+Fe) or AIS medium without Fe (-Fe). (A) Alkaline Comet assay on 14 days-old SHR-trap 1445 c0, pH 7.7 s1, pH 7.7 s1 pH $7.7 \mathrm{~s} 2$ seedlings, when germinated in control $(+\mathrm{Fe})$ or in $-\mathrm{Fe}$ AIS medium. One hundred cells were scored for each sample. Values are expressed as mean \pm SD of three replicates from two independent experiments. (B) Expression profiles of AtTFIIS (in blue) and AtTFIIS-like genes (in red) in the samples described in (A), by qRT-PCR analysis. Values are the result of three independent experiments and have been normalized to the expression value in control $\mathrm{c0}$ grown in $+\mathrm{Fe}$. Statistically significant differences (with respect to control $c 0$ ) are indicated with * $(p<0.05)$, according to Student's $t$-test.

expression, under Fe deficiency, even if not striking, may be of relevance for the Fe deficiency response.

\section{Photosynthetic Parameters in s1, s1s2, and s1c2 Generations: Oxygen Evolution, Chlorophyll Content, and Protein Composition of the Photosynthetic Apparatus}

$\mathrm{O}_{2}$ evolution was higher in $\mathrm{pH} 7.7 \mathrm{~s} 1 \mathrm{pH} 7.7$ s2 SHR-trap line seedlings than in control $\mathrm{c} 0$, when both were grown in $+\mathrm{Fe}$, thus suggesting that the photosynthetic apparatus is more efficient in seedlings whose parental plants experienced $\mathrm{Fe}$ deficiency (Figure 6A), in agreement with what was observed for chlorophyll content. Interestingly, $\mathrm{O}_{2}$ evolution values were not significantly higher in $\mathrm{pH} 7.7 \mathrm{~s} 1 \mathrm{c} 2$ than in control c0 (Figure 6A), indicating a loss of this trait in the offspring unexposed to stress. When seedlings are illuminated with light intensities well above growth light, i.e., at $800 \mu \mathrm{E} \mathrm{m}^{-2} \mathrm{~s}^{-1}$ (Figure 6A), the higher $\mathrm{O}_{2}$ evolution in $\mathrm{pH} 7.7 \mathrm{~s} 1 \mathrm{pH} 7.7 \mathrm{~s} 2$ is no longer statistically significant (Figure 6A).

These results show that $\mathrm{O}_{2}$ evolution was higher in seedlings grown in control conditions and with parental plants which had experienced Fe deficiency, in agreement with what was observed for chlorophyll content; however, this trait was lost within two generations unexposed to stress. 
A

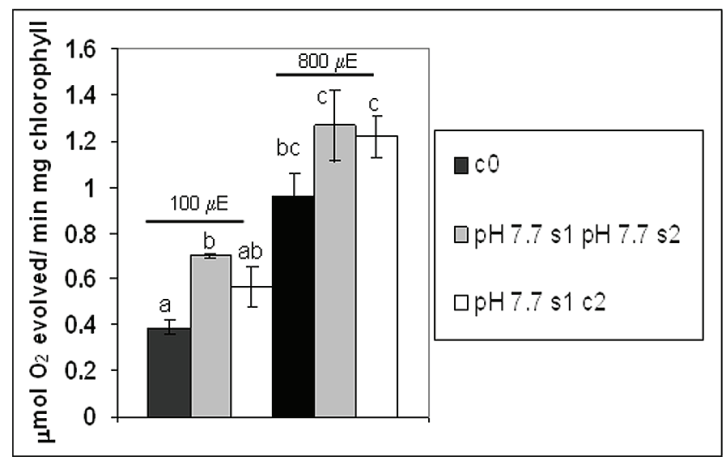

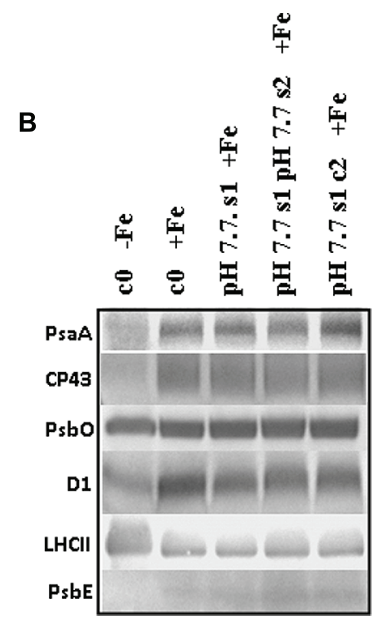

FIGURE $6 \mid \mathrm{O}_{2}$ evolution and protein profile of photosynthetic apparatus in $A$. thaliana seedlings with generational exposure to Fe deficiency. (A) SHR-trap $1445 \mathrm{c0}, \mathrm{pH} 7.7 \mathrm{~s} 1 \mathrm{pH} 7.7 \mathrm{~s} 2, \mathrm{pH} 7.7 \mathrm{~s} 1 \mathrm{c} 2$ seedlings were grown for 11 days in control AIS medium and net $\mathrm{O}_{2}$ evolution (expressed as $\mu$ mol $\mathrm{O}_{2}$ evolved $\mathrm{min}^{-1} \mathrm{mg}$ chlorophyll ${ }^{-1}$ ) was measured under illumination at either 100 or $800 \mu \mathrm{E} \mathrm{m}^{-2} \mathrm{~s}^{-1}$. Values are mean $\pm \mathrm{SE}$ of three biological replicas, each consisting of at least 15 seedlings. Letters represent statistical differences, according to Student's $t$-test, with $p<0.05$. (B) Western blot analysis with antibodies against PsaA, CP43, PsbO, D1, LHCII, and PsbE of thylakoid membranes purified from 11 days-old SHR-trap $1445 \mathrm{cO}$ seedlings germinated in -Fe AIS medium or from 11 days-old SHR-trap 1445 c0, pH 7.7 s1, pH 7.7 s1 pH 7.7 s2, pH 7.7 s1 c2 seedlings germinated in control (+Fe) AlS medium. Samples corresponding to $1 \mu \mathrm{g}$ chlorophyll were loaded on each lane.

As a result of Fe deficiency, changes in the protein profiles of different plant parts and compartments, among which are the thylakoid membranes, have been reported (Andaluz et al., 2006; López-Millán et al., 2013). Within the thylakoid membranes, both photosystem I (PSI) and photosystem II (PSII) are affected by Fe deficiency; however, it can be expected that there will be a more severe effect on PSI than on PSII, due to its higher number of Fe atoms per photosystem: $14 \mathrm{Fe}$ atoms/PSI versus $2 \mathrm{Fe}$ atoms/PSII (Yadavalli et al., 2012; Briat et al., 2015).

To further explore the impact of Fe deficiency stress and the existence of the memory of such stress on the protein composition of the photosynthetic apparatus, the reaction center subunits of PSI, PsaA, and of PSII, D1, together with other PSII polypeptides, among which the inner antenna protein $\mathrm{CP} 43$, the outer antenna protein LHCII, the extrinsic polypeptide of the Oxygen Evolving Complex PsbO and the PsbE protein (a subunit of cytochrome $b_{559}$ binding an heme cofactor), were analyzed by SDS-PAGE and western blotting, in $\mathrm{c} 0$ seedlings germinated in $-\mathrm{Fe}$, as well as in $\mathrm{c} 0, \mathrm{pH} 7.7 \mathrm{~s} 1, \mathrm{pH} 7.7 \mathrm{~s} 1$ $\mathrm{pH} 7.7$ s2, $\mathrm{pH} 7.7$ s1 c2 seedlings when germinated in $+\mathrm{Fe}$ (Supplementary Figure S3 and Figure 6B). Upon equal loading of chlorophyll in the protein gels for all analyzed samples, the amount of PsaA, as well as that of CP43 and D1, was dramatically reduced in $-\mathrm{Fe} \mathrm{c} 0$ seedlings, when compared with $+\mathrm{Fe}$ c0 seedlings (Figure 6B). Such results are in agreement with proteomic profiles observed in thylakoids isolated from Fedeficient Beta vulgaris leaves (Andaluz et al., 2006). However, it should be noted that such a decrease in PsaA has not been observed in Fe-deficient rice seedlings (Yadavalli et al., 2012). Fe deficiency dramatically affects the level of cytochrome $b_{559}$ in - Fe c0 seedlings, indeed its a subunit, PsbE, could not be detected in $-\mathrm{Fe}$ c0 seedlings (Figure 6B). Notably, under Fe deficiency, no decrease was observed in the amount of the PsbO subunit in any of the tested samples, thus suggesting that, at least in A. thaliana, Fe deficiency does not equally affect all the protein components of the two photosystems. Lastly and conversely to the behavior of the reaction center proteins of PSI (PsaA) and PSII (D1), and the inner antenna protein of PSII (CP43), the amount of the peripheral antenna proteins LHCII was not reduced in $-\mathrm{Fe}$ c0 seedlings when compared to any other $+\mathrm{Fe}$ samples.

A lack of substantial alterations in the protein profile of photosynthetic proteins in any of the generations grown in $+\mathrm{Fe}$, i.e., $\mathrm{pH} 7.7$ s1, pH 7.7 s1 pH 7.7 s2 and in pH 7.7 s1 c2, when compared to $+\mathrm{Fe} \mathrm{c} 0$ seedlings (Figure 6B), could be observed.

To further investigate chlorophyll as a hallmark of growth of the mother plant under Fe deficiency, the various $\mathrm{c} 0, \mathrm{~s} 1$, s1s2, s1c2 generations of wt $\mathrm{Col}$, described in Figure 1, were also tested by growing seedlings in control $(+\mathrm{Fe})$ or $-\mathrm{Fe}$ medium. As already observed for SHR-trap line (Figure 3B), chlorophyll content was higher in $\mathrm{pH} 7.7$ s1, pH 7.7 s1 pH 7.7 s2, $\mathrm{pH} 8.4 \mathrm{~s} 1$ and $\mathrm{pH} 8.4 \mathrm{~s} 1 \mathrm{pH} 8.4$ s2 Col seedlings, when compared to $\mathrm{c} 0 \mathrm{Col}$ seedlings in same condition (Supplementary Figure S4). Interestingly, chlorophyll concentration was higher in $\mathrm{pH} 7.7 \mathrm{~s} 1 \mathrm{c} 2$ and $\mathrm{pH} 8.4 \mathrm{~s} 1 \mathrm{c} 2$ offspring grown in control conditions than c0 itself (Supplementary Figure S4), indicating that this trait can be maintained for more than one offspring generation unexposed to stress. Also, the plateau effect observed for SHR events (Figures 2 and 4), DNA damage (Figure 5A), expression of TFIIS-like (Figure 5B) is confirmed once more, since chlorophyll content was statistically similar in $\mathrm{pH} 7.7 \mathrm{~s} 1$ and $\mathrm{pH} 7.7 \mathrm{~s} 1 \mathrm{pH} 7.7 \mathrm{~s} 2$ seedlings, as well as in $\mathrm{pH} 8.4 \mathrm{~s} 1$ and $\mathrm{pH} 8.4 \mathrm{~s} 1 \mathrm{pH} 8.4 \mathrm{~s} 2$ seedlings, when grown in control conditions (Supplementary Figure S4). 


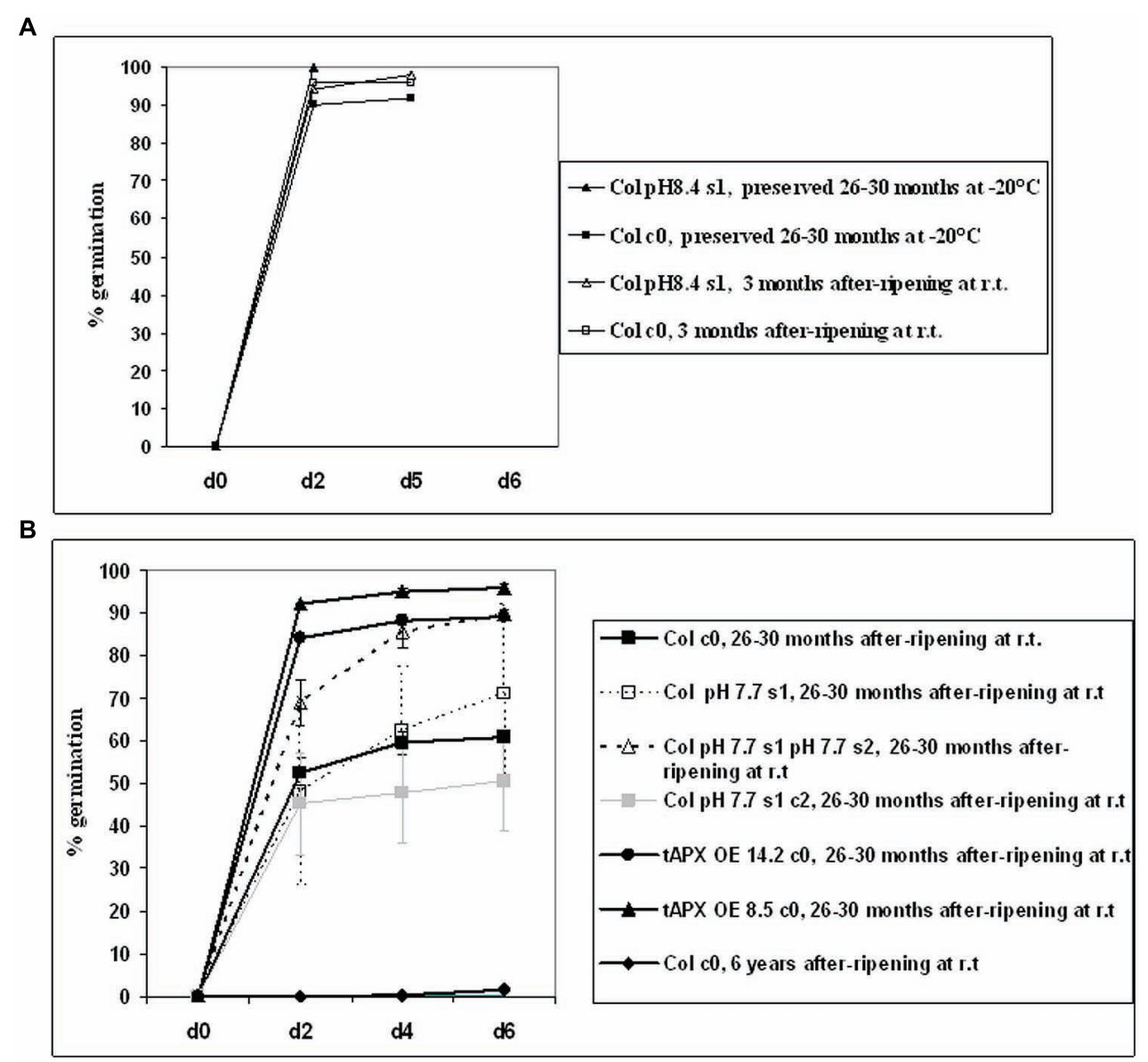

FIGURE 7 | Germination of $\boldsymbol{A}$. thaliana seeds, produced from plants with transgenerational exposure to Fe deficiency. (A) Germination of $\mathrm{c0}$ or $\mathrm{pH} 8.4 \mathrm{~s} 1$ Col seeds, after-ripened at room temperature for 3 months, or preserved at $-20^{\circ} \mathrm{C}$ for $26-30$ months. (B) Germination of c0, $\mathrm{pH} 7.7 \mathrm{~s} 1, \mathrm{pH} 7.7 \mathrm{~s} 1 \mathrm{pH} 7.7 \mathrm{~s} 2, \mathrm{pH}$ $7.7 \mathrm{~s} 1 \mathrm{c} 2 \mathrm{Col}$ seeds, after-ripened for 26-30 months at room temperature. As controls, c0 14.2 tAPX OE, 8.5 tAPX OE seeds after ripened for 26-30 months at room temperature as well as $\mathrm{cO} \mathrm{Col}$ seeds after-ripened for 6 years at room temperature were also used. Values correspond to mean percent germination $\pm \mathrm{SE}$ from at least three plates containing 100 seeds each.

The various wt Col generations described above were also germinated in $-\mathrm{Fe}$; as expected (see also Figure 3B) a reduction in chlorophyll content was observed in -Fe seedlings when compared to control ones (Supplementary Figure S4). The tested s1, s1s2, and s1c2 seedlings showed chlorophyll content of variable intensity, with respect to $\mathrm{c} 0$, when in $-\mathrm{Fe}$ (Supplementary Figure S4). Such an effect was not observed in the SHR-trap line (Figure 3), where all tested seedlings, when in $-\mathrm{Fe}$, showed the same chlorophyll content, regardless of stress pedigree.

\section{Seed Longevity Increases in s1s2 Seeds but not in s1c2 Ones}

Seed longevity can be severely affected due to oxidative damage occurring during prolonged storage and/or exposure to unfavorable environmental conditions (Donà et al., 2013). As a consequence of aging, seed viability is compromised (Kranner et al., 2010). In order to assess the effects of Fe deficiency on seed quality, germination of after-ripened (stored at room temperature) or of dormancy-preserved (stored at $-20^{\circ} \mathrm{C}$ ) Col $\mathrm{c} 0$, s1, s1s2, s1c2 generations was assessed; for that, seed batches of various ages were used ( 3 months, $26-30$ months, and 6 yearsold seeds). As positive controls, after-ripened 26-30 months-old c0 seeds of the transgenic A. thaliana lines tAPX OE 14.2 and tAPX OE 8.5 overexpressing thylakoidal ascorbate peroxidase, which show an enhanced resistance to oxidative stress (Murgia et al., 2004) were also used; these lines allowed to investigate plant responses to various abiotic and biotic oxidative stresses (Murgia et al., 2004; Yao and Greenberg, 2006; Laloi et al., 2007; Skirycz et al., 2011). Nomenclature of all the tested seeds that keeps track of stress history of the mother plants is according to Figure 1.

Germination curves at $25^{\circ} \mathrm{C}$ in the light were assessed over a 6-days time span, as a proxy for seed longevity; for that, seeds were first cold-stratified ( 4 days at $4^{\circ} \mathrm{C}$ in the dark) to break any residual dormancy and to promote synchronous germination.

As expected, young (3 months-old) after-ripened $\mathrm{c} 0$ or $\mathrm{pH}$ $8.4 \mathrm{~s} 1 \mathrm{Col}$ seeds all germinated within 2 days; full germination was also observed in older (26-30 months-old) c0 seeds, if stored 
at $-20^{\circ} \mathrm{C}$ (Figure 7A). Next, germination of $\mathrm{c} 0, \mathrm{pH} 7.7 \mathrm{~s} 1, \mathrm{pH}$ $7.7 \mathrm{~s} 1 \mathrm{pH} 7.7 \mathrm{~s} 2$, pH $7.7 \mathrm{~s} 1 \mathrm{c} 2$ after-ripened 26-30 months $\mathrm{Col}$ seeds was measured. Germination of $\mathrm{c} 0 \mathrm{Col}$ seeds was below $50 \%$ (Figure 7B) and therefore much lower than that of same-age seeds stored at $-20^{\circ} \mathrm{C}$ (Figure 7A). Germination of pH $7.7 \mathrm{~s} 1 \mathrm{pH}$ $7.7 \mathrm{~s} 2 \mathrm{Col}$ seeds was much higher, being above $80 \%$ (Figure 7B), whereas germination curves similar to control were observed in pH $7.7 \mathrm{~s} 1$ or pH $7.7 \mathrm{~s} 1 \mathrm{c} 2 \mathrm{Col}$ seeds (Figure 7B). Unfortunately, lack of 26-30 months after-ripened pH $7.7 \mathrm{~s} 1 \mathrm{pH} 7.7 \mathrm{~s} 2 \mathrm{c} 3 \mathrm{Col}$ seeds prevented us from further exploring longevity traits. Lastly, 26-30 months after-ripened c0 14.2 and 8.5 tAPX OE seeds (used as positive controls) showed $90-100 \%$ germination (Figure 7B), as high as that observed in young ( 3 months-old) after-ripened wt Col seeds, whereas fairly old c0 Col seeds (6 years after ripening) did not germinate (Figure 7B).

These results showed that growth of more than one generation under Fe deficiency has a positive impact on the longevity of seeds produced.

\section{Discussion}

The analysis of stress-induced plant priming and related transgenerational stress memory have been intensively debated due to their great potential for crop improvement (Hauser et al., 2011; Vriet et al., 2015). Transgenerational memory could be of advantage for subsequent generations exposed to nutritional stress: indeed, in the open, some environmental abiotic stresses such as cold, drought, etc. might not even occur during offspring growth, due to fluctuations of environmental conditions; even pathogen attacks might be limited in time. In such cases, the advantage of "erasing" any memory of stress that means all the burden of epigenetic modification, might outbalance the advantage of maintaining the memory of that stress in the progeny. Vice-versa, nutritional deficiencies due to soil composition are chronic stresses that hardly change with time and therefore, in such a case, the maintenance of the burden of epigenetic modifications induced by nutritional stresses might be of advantage for plants whose seeds often fall in close proximity to the mother plant. Despite the increase in recent years of reports on transgenerational stress memory, including the effects of nutrients limitations (Kou et al., 2011; Verhoeven and van Gurp, 2012), up to now, the stable inheritance of Fe deficiency stress memory in offspring generations has not been analyzed.

We investigated, for the first time, whether a genuine transgenerational memory of Fe deficiency stress occurs in the model plant $A$. thaliana; we demonstrated that Fe deficiency alters DNA damage and repair and we analyzed such traits in unstressed offspring (Vriet et al., 2015); moreover, we also analyzed physiological effects of $\mathrm{Fe}$ deficiency occurring in unstressed offspring (Verhoeven and van Gurp, 2012), such as the status of the photosynthetic apparatus (chlorophyll content, $\mathrm{O}_{2}$ evolution, protein profile) and also seed longevity; all these traits are indeed agronomically and economically relevant.

Most importantly, we analyzed such traits not only in the first generation but also in the second one, with and without stress, to distinguish genuine transgenerational memory from other possible mechanisms, such as transmission, from mother to progeny plant, of enzymes, toxins, hormones, etc. which can be observed in progeny but do not represent genuine memory (Paszkowski and Grossniklaus, 2011; Verhoeven and van Gurp, 2012).

We showed that frequency of DNA damage and repair, evaluated through events of SHR and DNA strand breaks, increased in plants grown under various conditions of $\mathrm{Fe}$ deficiency (mild or severe alkaline soil, depletion of Fe from medium); however, their frequencies returned to control values within one or two offspring generations, as was also observed for SHR induced by various stresses and described in Pecinka et al. (2009). It was interesting that SHR frequency, in s1 or s2 generations unexposed to stress, immediately declined to control levels in experiments conducted in controlled medium, whereas it took one more generation in experiments conducted in soil; such lasting "stress memory" in soil, at least for one unstressed generation, but not in medium, suggests that growth in alkaline soil might trigger a more complex response to stress than the Fe deficiency response obtained by simple Fe deprivation. Nevertheless, the need to obtain sufficient amounts of seeds from plants exposed to $\mathrm{Fe}$ deficiency stress and with different stress pedigrees, together with the fact that soil alkalinisation is indeed the most common cause of Fe deficiency encountered by plants in the open, prevented us from choosing to carry out in vitro experiments only. Anyway, the data obtained from mild or severe alkaline $\mathrm{pH}(\mathrm{pH} 7.7$ or $\mathrm{pH}$ 8.4) confirmed the consistency of results obtained with soil-grown plants.

We also analyzed some photosynthetic parameters: chlorophyll content, $\mathrm{O}_{2}$ evolution, protein composition of photosynthetic apparatus. Chlorophyll content was still altered in two offspring generations unexposed to stress; however, erasure of such alteration in further generations might be supposed. Indeed, results of increased chlorophyll content, in offspring of plants grown under Fe deficiency and described in the present work, were occasionally not reproducible, as already reported for other transgenerational phenotypic effects: as an example, apomictic dandelion (Taraxacum officinale, common dandelion) grown under nutrients limitation, shows increased root:shoot ratio in offspring produced from plants grown under the same nutritional stress compared with the offspring from plants grown under control conditions: however, such a phenotype was variable and could not be always reproduced within the same lab and from the same authors (Verhoeven and van Gurp, 2012). As already pointed out by these authors, such lack of full consistency among various experiments, as far as chlorophyll content is concerned, could be due to subtle differences among experimental conditions which might override parental effects (Verhoeven and van Gurp, 2012).

Moreover, $\mathrm{pH} 7.7 \mathrm{~s} 1 \mathrm{c} 2$ seedlings, when germinated in control conditions, evolved less oxygen than $\mathrm{pH} 7.7 \mathrm{~s} 1 \mathrm{pH} 7.7 \mathrm{~s} 2$ seedlings in the same conditions. Provided that the chlorophyll content could be further tested in the offspring of the various generations already described in the present work, all the photosynthetic parameters measured so far do not support the existence of a 
genuine and reproducible transgenerational transmission of memory. The same observations apply to the increased weight, not always observed in s1 progeny grown in control conditions, as reported in the present work; also in such a case, subtle differences among experimental conditions which might override parental effects.

Arabidopsis thaliana AtTFIIS-like is one of the putative proteins of subunit 26 of the Mediator complex, i.e., MED26_3 (Mathur et al., 2011); although its expression is only slightly induced by Fe deficiency, nevertheless the expression of MED16, another subunit of Mediator which is undoubtedly involved in the regulation of the $\mathrm{Fe}$ deficiency response (Yang et al., 2014; Zhang et al., 2014), does not change at all under Fe deficiency, making the observed change in AtTFIIS-like gene expression, profoundly relevant. The reported data, highlighting the involvement of the TFIIS-like gene in the plant response to Fe-deficiency stress, provide for the first time evidence of the role played in this context by the TC-NER sub-pathway. The latter is critical for cell survival due to its anti-mutagenic properties, which protect DNA against the long-term effects of genotoxic stress (Fousteri and Mullenders, 2008). TCNER, which specifically acts on the transcribed regions of the genome, thus preserving gene expression, has been previously demonstrated to participate in the response to gamma irradiation (Macovei et al., 2014), as well as heavy metals and osmotic stresses (Macovei et al., 2011). The present work contributes to further expand the range of stresses that trigger TC-NER, but also significantly contributes to the current scientific discussions on the putative link between transgenerational memory and DNA repair response in plants.

Longevity of seeds represents a research focus of several groups, due to the tremendous ecological, economic and nutritional impact that such physiological processes have (Devaiah et al., 2007) and indeed one of the most important questions facing plant science research is what determines seed longevity and dormancy (Grierson et al., 2011). The observed phenotype of increased longevity in offspring seeds of $\mathrm{Fe}$ deficiency stressed mother plants is new in the nutritional field and it also encourages further investigation in order to clarify the link between seed longevity, Fe content, its localization and mobilization as well as levels of different ROS species, in seeds produced from mother plants grown under Fe deficiency.

The next step in the elucidation of the Fe-deficiency associated traits described in the present work will be to understand if and how their molecular regulation is associated with epigenetic modifications.

\section{References}

Andaluz, S., Lopez-Millan, A. F., De las Rivas, J., Aro, E. M., Abadia, J., and Abadia, A. (2006). Proteomic profiles of thylakoid membranes and changes in response to iron deficiency. Photosynth. Res. 89, 141-155. doi: 10.1007/s11120006-9092-6

Aranega-Bou, P., de la O Leyva, M., Finiti, I., Garcia-Augustin, P., and Gonzalez-Bosch, C. (2014). Priming of plant resistance by natural compounds. Hexanoic acid as a model. Front. Plant Sci. 5:488. doi: 10.3389/fpls.2014. 00488

\section{Conclusion}

We described for the first time profiles of SHR events and of DNA damage, occurring under Fe deficiency in A. thaliana and we also identified a new Fe-deficiency responsive gene, i.e., AtTFIIS-like. We then analyzed SHR, DNA damage, AtTFIISlike gene expression, as well as a set of physiological parameters in a multiple-generation cohort of plants with different stress pedigrees. The data obtained suggest the existence of multiplestep control of mechanisms orchestrating the prevention of a genuine and stable transgenerational transmission of $\mathrm{Fe}$ deficiency stress memory, with the tightest control on DNA integrity. The production of a wider cohort of s3 (and successive) plant generations and the analysis of traits such as chlorophyll content, $\mathrm{O}_{2}$ evolution and in particular seed longevity in such extended cohort, when grown either in presence or absence of stress, will allow to further test this hypothesis.

\section{Author Contributions}

IM conceived the work and wrote the manuscript; IM, SG, AB, SP, $\mathrm{CP}$, and PM contributed the data; IM, SG, and PM contributed to the analysis and the discussion of data.

\section{Acknowledgments}

We thank Prof. Holger Putchta and Dr. Alexander Knoll for providing the A. thaliana SHR-trap 1445 line and Prof. Roberto Barbato for providing antibodies against LHCII. SP was financed by a Research Fellowship award from Regione Lombardia D.G. Istruzione, Formazione e Lavoro, Struttura Asse V-Interregionalità e Transnazionalità POR FSE 20072013, Project ID 46547514 'Advanced Priming Techniques for the Lombardy Agro-Seed Industry-PRIMTECH' (Action 2). $\mathrm{CP}$ was financed by the Italian Ministry of Education, University and Research, "Futuro in Ricerca 2013" program RBFR1334SB.

\section{Supplementary Material}

The Supplementary Material for this article can be found online at: http://journal.frontiersin.org/article/10.3389/fpls.2015.00745

Arnon, D. J. (1949). Copper enzymes in isolated chloroplasts. Polyphenoloxidase in Beta vulgaris. Plant Physiol. 24, 1-14. doi: 10.1104/pp. 24.1.1

Balestrazzi, A., Confalonieri, M., Macovei, A., Donà, M., and Carbonera, D. (2011). Genotoxic stress and DNA repair in plants: emerging functions and tools for improving crop productivity. Plant Cell Rep. 30, 287-295. doi: 10.1007/s00299010-0975-9

Balmer, A., Pastor, V., Gamir, J., Flors, V., and Mauch-Mani, B. (2015). The 'primeome': towards a holistic approach to priming. Trends Plant Sci. 20, 443-452. doi: 10.1016/j.tplants.2015.04.002 
Beekwilder, J., van Leeuwen, W., van Dam, N. M., Bertossi, M., Grandi, V., Mizzi, L., et al. (2008). The impact of the absence of aliphatic glucosinolates on insect herbivory in Arabidopsis. PLoS ONE 3:e2068. doi: 10.1371/journal.pone.0002068

Berri, S., Abbruscato, P., Faivre-Rampant, O., Brasileiro, A. C., Fumasoni, I., Satoh, K., et al. (2009). Characterization of WRKY co-regulatory networks in rice and Arabidopsis. BMC Plant Biol. 9:120. doi: 10.1186/1471-22299-120

Bilichak, A., Ilnytskyy, Y., Woycicki, R., Kepeshchuk, N., Fogen, D., and Kovalchuk, I. (2015). The elucidation of stress memory inheritance in Brassica rapa plants. Front. Plant Sci. 6:5. doi: 10.3389/fpls.2015.00005

Boyko, A., Blevins, T., Yao, Y., Golubov, A., Bilichak, A., Ilnytskyy, Y., et al. (2010). Transgenerational adaptation of Arabidopsis to stress requires DNA methylation and the function of DICER-like proteins. PLoS ONE 5:e9514. doi: 10.1371/journal.pone.0009514

Briat, J. F., Dubos, C., and Gaymard, F. (2015). Iron nutrition, biomass production, and plant product quality. Trends Plant Sci. 20, 33-40. doi: 10.1016/j.tplants.2014.07.005

Collins, A. R. (2004). The comet assay for DNA damage and repair. Mol. Biotechnol. 26, 249-261. doi: 10.1385/MB:26:3:249

Conrath, U., Beckers, G. J. M., Flors, V., García-Agustín, P., Jakab, G., Mauch, F., et al. (2006). Priming: getting ready for battle. Mol. Plant Microbe Interact. 19, 1062-1071. doi: 10.1094/MPMI-19-1062

Crevillen, P., Yang, H., Cui, X., Greeff, C., Trick, M., Qiu, Q., et al. (2014). Epigenetic reprogramming that prevents transgenerational inheritance of the vernalized state. Nature 515, 587-590. doi: 10.1038/nature13722

Devaiah, S. P., Pan, X., Hong, Y., Roth, M., Welti, R., and Xuemin Wang, X. (2007). Enhancing seed quality and viability by suppressing phospholipase D in Arabidopsis. Plant J. 50, 950-957. doi: 10.1111/j.1365-313X.2007.03103.x

Donà, M., Balestrazzi, A., Mondoni, A., Rossi, G., Ventura, L., Buttafava, A., et al. (2013). DNA profiling, telomere analysis and antioxidant properties as tools for monitoring ex situ seed longevity. Ann. Bot. 111, 987-998. doi: $10.1093 / \mathrm{aob} / \mathrm{mct} 058$

Fousteri, M., and Mullenders, L. (2008). Transcription-coupled repair nucleotide excision repair in mammalian cells: biological mechanisms and molecular effects. Cell Res. 18, 73-84. doi: 10.1038/cr.2008.6

Fu, Z. Q., and Dong, Z. (2013). Systemic acquired resistance: turning local infection into global defence. Annu. Rev. Plant Biol. 64, 839-863. doi: 10.1146/annurevarplant-042811-105606

Goodstein, D., Shu, S., Howson, R., Neupane, R., Hayes, R. D., Fazo, J., et al. (2012). Phytozome, a comparative platform for green plant genomics. Nucleic Acids Res. 40, D1178-D1186. doi: 10.1093/nar/gkr944

Grasser, M., Kane, C. M., Merkle, T., Melzer, M., Emmersen, J., and Grasser, K. D. (2009). Transcript elongation factor TFIIS is involved in Arabidopsis seed dormancy. J. Mol. Biol. 386, 598-611. doi: 10.1016/j.jmb.2008.12.066

Grierson, C. S., Barnes, S. R., Chase, M. W., Clarke, M., Grierson, D., and Edwards, K. J. et al. (2011). One hundred important questions facing plant science research. New Phytol. 192, 6-12. doi: 10.1111/j.1469-8137.2011.03859.x

Hauser, M. T., Aufsatz, W., Jonak, C., and Luschnig, C. (2011). Transgenerational epigenetic inheritance in plants. Biochim. Biophys. Acta 1809, 459-468. doi: 10.1016/j.bbagrm.2011.03.007

Iwasaki, M., and Paszkowski, J. (2014). Identification of genes preventing transgenerational transmission of stress-induced epigenetic states. Proc. Natl. Acad. Sci. U.S.A. 111, 8547-8552. doi: 10.1073/pnas.1402275111

Jaskiewicz, M., Conrath, U., and Peterhänsel, C. (2011). Chromatin modification acts as a memory for systemic acquired resistance in the plant stress response. EMBO Rep. 12, 50-55. doi: 10.1038/embor.2010.186

Jeong, J., and Guerinot, M. L. (2009). Homing in on iron homeostasis in plants. Trends Plant Sci. 14, 280-285. doi: 10.1016/j.tplants.2009.02.006

Kieu, N. P., Aznar, A., Segond, D., Rigault, M., Simond-Cote, E., Kunz, C., et al. (2012). Iron deficiency affects plant defence responses and confers resistance to Dickeya dadantii and Botrytis cinerea. Mol. Plant Pathol. 13, 816-827. doi: 10.1111/j.1364-3703.2012.00790.x

Kobayashi, T., and Nishizawa, N. K. (2012). Iron uptake, translocation and regulation in higher plants. Annu. Rev. Plant Biol. 63, 131-152. doi: 10.1146/annurev-arplant-042811-105522

Kou, H. P., Li, Y., Song, X. X., Ou, X. F., Xing, S. C., Ma, J., et al. (2011). Heritable alteration in DNA methylation induced by nitrogen-deficiency stress accompanies enhanced tolerance by progenies to the stress in rice. J. Plant Physiol. 68, 1685-1693. doi: 10.1016/j.jplph.2011.03.017

Kranner, I., Minibayeva, F. V., Beckett, R. P., and Seal, C. E. (2010). What is stress? Concepts, definitions and applications in seed science. New Phytol. 188, 655-673. doi: 10.1111/j.1469-8137.2010.03461.x

Laemmli, U. K. (1970). Cleavage of structural proteins during the assembly of the head of bacteriophage T4. Nature 227, 680-685. doi: 10.1038/227680a0

Lagerwerf, S., Vrouwe, M. G., Overmeer, R. M., Fousteri, M. I., and Mullenders, L. H. (2011). DNA damage response and transcription. DNA Repair 10, 743750. doi: 10.1016/j.dnarep.2011.04.024

Laloi, C., Stachowiak, M., Pers-Kamczyc, E., Warzych, E., Murgia, I., and Apel, K. (2007). Cross-talk between singlet oxygen- and hydrogen peroxide-dependent signaling of stress response in Arabidopsis thaliana. Proc. Natl. Acad. Sci. U.S.A. 104, 672-677. doi: 10.1073/pnas.0609063103

Lee, K., and Seo, P. (2014). Airborne signals from salt-stressed Arabidopsis plants trigger salinity tolerance in neighboring plants. Plant Signal. Behav. 9:e28392. doi: $10.4161 /$ psb. 28392

Ling, Y., Smith, A. J., and Morgan, G. T. (2006). A sequence motif conserved in diverse nuclear proteins identifies a protein interaction domain utilised for nuclear targeting by human TFIIS. Nucleic Acids Res. 34, 2219-2229. doi: 10.1093/nar/gkl239

López-Millán, A. F., Grusak, M. A., Abadía, A., and Abadía, J. (2013). Iron deficiency in plants: an insight from proteomic approaches. Front. Plant Sci. 4:254. doi: 10.3389/fpls.2013.00254

Luna, E., Bruce, T. J. A., Roberts, M. R., Flors, V., and Ton, J. (2012). Nextgeneration systemic acquired resistance. Plant Physiol. 58, 844-853. doi: 10.1104/pp.111.187468

Macovei, A., Balestrazzi, A., Confalonieri, M., Buttafava, A., and Carbonera, D. (2011). The TFIIS and TFIIS-like genes from Medicago truncatula are involved in oxidative stress response. Gene 470, 20-30. doi: 10.1016/j.gene.2010. 09.004

Macovei, A., Garg, B., Raikwar, S., Balestrazzi, A., Carbonera, D., Buttafava, A., et al. (2014). Synergistic exposure of rice seeds to different doses of $\gamma$-Ray and salinity stress resulted in increased antioxidant enzyme activities and genespecific modulation of TC-NER pathway. Biomed. Res. Intern. 2014:676934. doi: $10.1155 / 2014 / 676934$

Mathur, S., Vyas, S., Kapoor, S., and Tyagi, A. K. (2011). The Mediator complex in plants: structure, phylogeny, and expression profiling of representative genes in a dicot (Arabidopsis) and a monocot (rice) during reproduction and abiotic stress. Plant Physiol. 157, 1609-1627. doi: 10.1104/pp.111.188300

Menges, M., Dóczi, R., Ökrész, L., Morandini, P., Mizzi, L., Soloviev, M., et al. (2008). Comprehensive gene expression atlas for the Arabidopsis MAP kinase signalling pathways. New Phytol. 179, 643-662. doi: 10.1111/j.14698137.2008.02552.x

Menke, M., Meister, A., and Schubert, I. (2000). N-Methyl-N-nitrosourea-induced DNA damage detected by the comet assay in Vicia faba nuclei during all interphase stages is not restricted to chromatid aberration hot spots. Mutagen 15, 503-506. doi: 10.1093/mutage/15.6.503

Mittler, R., Vanderauwera, S., Suzuki, N., Miller, G., Tognetti, V. B., Vanderpoele, K., et al. (2011). ROS signaling: the new wave? Trends Plant Sci. 16, 300-309. doi: 10.1016/j.tplants.2011.03.007

Molassiotis, A., Tanou, G., and Diamantidis, G. (2010). NO says more than 'YES' to salt tolerance. Salt priming and systemic nitric oxide signaling in plants. Plant Signal. Behav. 5, 209-212. doi: 10.4161/psb.5.3.10738

Molinier, J., Ries, G., Zipfel, C., and Hohn, B. (2006). Transgeneration memory of stress in plants. Nature 442, 1046-1049. doi: 10.1038/nature05022

Mortensen, S. A., and Grasser, K. D. (2014). The seed dormancy defect of Arabidopsis mutants lacking the transcript elongation factor TFIIS is caused by reduced expression of the DOG1 gene. FEBS Lett. 588, 47-51. doi: 10.1016/j.febslet.2013.10.047

Mukherjee, M., Larrimore, K. E., Ahemd, N. J., Bedick, T. S., Barghouthi, N. T., Traw, M. B., et al. (2010). Ascorbic acid deficiency in Arabidopsis induces constitutive priming that is dependent on hydrogen peroxide, salicylic acid and the NPR1 gene. Mol. Plant Microbe Interact. 23, 340-351. doi: 10.1094/MPMI23-3-0340

Murgia, I., Arosio, P., Tarantino, D., and Soave, C. (2012). Biofortification for combating "hidden hunger" for iron. Trends Plant Sci. 17, 47-55. doi: 10.1016/j.tplants.2011.10.003 
Murgia, I., De Gara, L., and Grusak, M. (2013). Biofortification: how can we exploit plant science to reduce micronutrient deficiencies? Front. Plant Sci. 4:429. doi: 10.3389/fpls.2013.00429

Murgia, I., Morandini, P., Moroni, A., and Soave, C. (1998). A non-destructive selection method for resistance to fusicoccin in Arabidopsis thaliana. Plant Cell Rep. 18, 255-259. doi: 10.1007/s002990050567

Murgia, I., Tarantino, D., Soave, C., and Morandini, P. (2011). Arabidopsis CYP82C4 expression is dependent on Fe availability and circadian rhythm, and correlates with genes involved in the early Fe deficiency response. J. Plant Physiol. 168, 894-902. doi: 10.1016/j.jplph.2010.11.020

Murgia, I., Tarantino, D., Vannini, C., Bracale, M., Carravieri, S., and Soave, C. (2004). Arabidopsis thaliana plants overexpressing thylakoidal ascorbate peroxidase show increased resistance to Paraquat-induced photooxidative stress and to nitric oxide-induced cell death. Plant J. 38, 940-953. doi: 10.1111/j.1365-313X.2004.02092.x

Pastor, V., Luna, E., Mauch-Mani, B., Ton, J., and Flors, V. (2013a). Primed plants do not forget. Environ. Exp. Bot. 94, 46-56. doi: 10.1016/j.envexpbot.2012.02.013

Pastor, V., Luna, E., Ton, J., Cerezo, M., García-Agustín, P., and Flors, V. (2013b). Fine tuning of reactive oxygen species homeostasis regulates primed immune responses in Arabidopsis. Mol. Plant Microbe Interact. 26, 1334-1344. doi: 10.1094/MPMI-04-13-0117-R

Paszkowski, J., and Grossniklaus, U. (2011). Selected aspects of transgenerational epigenetic inheritance and resetting in plants. Curr. Opin. Plant Biol. 14, 195-203. doi: 10.1016/j.pbi.2011.01.002

Pecinka, A., Rosa, M., Schikora, A., Berlinger, M., Hirt, H., Luschnig, C., et al. (2009). Transgenerational stress memory is not a general response in Arabidopsis. PLoS ONE 4:e5202. doi: 10.1371/journal.pone.0005202

Pieterse, C. M. J. (2012). Prime time for transgenerational defense. Plant Physiol. 58, 545. doi: 10.1104/pp.112.900430

Puchta, H., and Hohn, B. (2012). In planta somatic homologous recombination assay revisited: a successful and versatile, but delicate tool. Plant Cell 24, 4324-4331. doi: 10.1105/tpc.112.101824

Rasmann, S., De Vos, M., Casteel, C. L., Tian, D., Halitschke, R., Sun, J. Y., et al. (2012). Herbivory in the previous generation primes plants for enhanced insect resistance. Plant Physiol. 58, 854-863. doi: 10.1104/pp.111.187831

Ravet, K., and Pilon, M. (2013). Copper and iron homeostasis in plants: the challenges of oxidative stress. Antiox. Redox Signall. 19, 919-932. doi: 10.1089/ars.2012.5084

Ravet, K., Touraine, B., Boucherez, J., Briat, J. F., Gaymard, F., and Cellier, F. (2009). Ferritins control interaction between iron homeostasis and oxidative stress in Arabidopsis. Plant J. 57, 400-412. doi: 10.1111/j.1365-313X.2008.03698.x

Shevchenko, A., Wilm, M., Vorm, O., and Mann, M. (1996). Mass spectrometric sequencing of proteins silver-stained polyacrylamide gels. Anal. Chem. 68, 850-858. doi: 10.1021/ac950914h

Skirycz, A., Vandenbroucke, K., Clauw, P., Maleux, K., De Meyer, B., Dhondt, S., et al. (2011). Survival and growth of Arabidopsis plants given limited water are not equal. Nat. Biotechnol. 29, 211-214. doi: 10.1038/nbt.1800

Slaughter, A., Daniel, X., Flors, V., Luna, E., Hohn, B., and Mauch-Mani, B. (2012). Descendants of primed Arabidopsis plants exhibit resistance to biotic stress. Plant Physiol. 58, 835-843. doi: 10.1104/pp.111.191593
Tarantino, D., Vannini, C., Bracale, M., Campa, M., Soave, C., and Murgia, I. (2005). Antisense reduction of thylakoidal ascorbate peroxidase in Arabidopsis enhances Paraquat-induced photooxidative stress and nitric oxide-induced cell death. Planta 221, 757-765. doi: 10.1007/s00425-005-1485-9

Tinland, B., Hohn, B., and Puchta, H. (1994). Agrobacterium tumefaciens transfers single-stranded transferred DNA (T-DNA) into the plant cell nucleus. Proc. Natl. Acad. Sci. U.S.A. 91, 8000-8004. doi: 10.1073/pnas.91.17.8000

Tittel-Elmer, M., Bucher, E., Broger, L., Matheu, O., Paszkowski, J., and Vaillant, I. (2010). Stress-induced activation of heterochromatin transcription. PloS Genet. 6:e1001175. doi: 10.1371/journal.pgen.1001175

Vandesompele, J., De Preter, K., Pattyn, F., Poppe, B., Van Roy, N., De Paepe, A., et al. (2002). Accurate normalization of real-time quantitative RT-PCR data by geometric averaging of multiple internal control genes. Genome Biol. 3:RESEARCH0034.

Verhoeven, K. J. F., and van Gurp, T. P. (2012). Transgenerational effects of stress exposure on offspring phenotypes in apomictic dandelion. PLoS ONE 7:e38605. doi: 10.1371/journal.pone.0038605

Vigani, G., Zocchi, G., Bashir, K., Philippar, K., and Briat, J. F. (2013). Signals for chloroplast and mitochondria for iron homeostasis regulation. Trends Plant Sci. 18, 305-311. doi: 10.1016/j.tplants.2013.01.006

Vriet, C., Hennig, L., and Laloi, C. (2015). Stress-induced chromatin changes in plants: of memories, metabolites and crop improvement. Cell. Mol. Life Sci. 72, 1261-1273. doi: 10.1007/s00018-014-1792-z

Waterworth, W. M., Drury, G. E., Bray, C. M., and West, C. E. (2011). Repairing breaks in the plant genome: the importance of keeping it together. New Phytol. 192, 805-822. doi: 10.1111/j.1469-8137.2011.03926.x

Yadavalli, V., Neelam, S., Rao, A. S. V. C., Reddy, A. R., and Subramanyam, R. (2012). Differential degradation of photosystem I subunit under iron deficiency in rice. J. Plant Physiol. 169, 753-759. doi: 10.1016/j.jplph.2012.02.008

Yang,Y., Ou, B., Zhang, J., Si, W., Gu, H., Qin, G., et al. (2014). The Arabidopsis mediator subunit MED16 regulates iron homeostasis by associating with EIN3/EIL1 through subunit MED25. Plant J. 77, 838-851. doi: 10.1111/tpj.12440

Yao, N., and Greenberg, J. T. (2006). Arabidopsis ACCELERATED CELL DEATH2 modulates programmed cell death. Plant Cell 18, 397-411. doi: 10.1105/tpc.105.036251

Zhang, Y., Wu, H., Wang, N., Fan, H., Chen, C., Cui, Y., et al. (2014). Mediator subunit 16 functions in the regulation of iron uptake gene expression in Arabidopsis. New Phytol. 203, 770-783. doi: 10.1111/nph.12860

Conflict of Interest Statement: The authors declare that the research was conducted in the absence of any commercial or financial relationships that could be construed as a potential conflict of interest.

Copyright (C) 2015 Murgia, Giacometti, Balestrazzi, Paparella, Pagliano and Morandini. This is an open-access article distributed under the terms of the Creative Commons Attribution License (CC BY). The use, distribution or reproduction in other forums is permitted, provided the original author(s) or licensor are credited and that the original publication in this journal is cited, in accordance with accepted academic practice. No use, distribution or reproduction is permitted which does not comply with these terms. 